\title{
The Crossroad of Ion Channels and Calmodulin in Disease
}

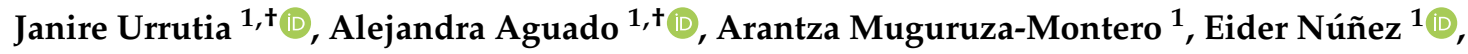 \\ Covadonga Malo ${ }^{1}$, Oscar Casis ${ }^{2}$ and Alvaro Villarroel ${ }^{1, *}$ \\ 1 Biofisika Institute (CSIC, UPV/EHU), University of the Basque Country, 48940 Leioa, Spain; \\ janire.urrutia@gmail.com (J.U.); alejandra.aguado@ehu.eus (A.A.); \\ arantza.muguruza.montero@gmail.com (A.M.-M.); enviadero@gmail.com (E.N.); \\ covadonga.m@gmail.com (C.M.) \\ 2 Departamento de Fisiología, Facultad de Farmacia, Universidad del País Vasco (UPV/EHU), \\ 01006 Vitoria-Gasteiz, Spain; oscar.casis@ehu.eus \\ * Correspondence: alvaro.villarroel@csic.es; Tel.: +34-9460-13225 \\ + These authors contributed equally to this work.
}

Received: 14 December 2018; Accepted: 16 January 2019; Published: 18 January 2019

\begin{abstract}
Calmodulin (CaM) is the principal $\mathrm{Ca}^{2+}$ sensor in eukaryotic cells, orchestrating the activity of hundreds of proteins. Disease causing mutations at any of the three genes that encode identical CaM proteins lead to major cardiac dysfunction, revealing the importance in the regulation of excitability. In turn, some mutations at the CaM binding site of ion channels cause similar diseases. Here we provide a summary of the two sides of the partnership between CaM and ion channels, describing the diversity of consequences of mutations at the complementary CaM binding domains.
\end{abstract}

Keywords: calmodulin; ion channels; channelopathies; calcium

\section{Universal Calcium Signaling}

Calcium is a universal signaling messenger involved in fundamental processes, including muscle contraction, long-term potentiation, apoptosis, or cell proliferation $[1,2]$. While $\mathrm{Ca}^{2+}$ concentration at the extracellular milieu or at intracellular storage compartments is of the order of $2 \mathrm{mM}$, intracellular $\mathrm{Ca}^{2+}$ is kept in the low-to-mid nanomolar range, establishing a step 20,000-fold gradient. Since $\mathrm{Ca}^{2+}$ is toxic to the cell, signaling by this cation has to be brief and tightly controlled [2]. Upon cellular stimulation, different mechanisms lead to transient intracellular increases in $\mathrm{Ca}^{2+}$ concentrations that initiate different protein activities. Most proteins are devoid of $\mathrm{Ca}^{2+}$ binding sites, requiring a mediator to respond to this cation [1]. The ability to transmit conformational changes to a large and diverse array of proteins in response to $\mathrm{Ca}^{2+}$ oscillations, coordinating the activity of hundreds of proteins, makes calmodulin (CaM, see a list of Abbreviations) the most important $\mathrm{Ca}^{2+}$ signal transducer in eukaryotic cells. CaM, initially named, among others, $\mathrm{Ca}^{2+}$-dependent regulator (CDR), was discovered in 1970 by Cheung and Kakiuchi as a $\mathrm{Ca}^{2+}$-dependent regulator of cyclic nucleotide phosphodiesterase in the brain [3-5]. Since then, the number of proteins and functions regulated by CaM keeps on expanding, including kinases, phosphatases, metabolic enzymes, ion channels, pumps, transcription factors, and many other proteins from yeast to humans [6]. The ability to bind and regulate such a large and diverse array of proteins resides in its inherent flexible nature that allows to fit structurally into more than 300 target proteins and to trigger diverse regulatory mechanisms. 


\section{Calmodulin Links Chemical and Electrical Signals}

The linkage between $\mathrm{Ca}^{2+}, \mathrm{CaM}$, and cellular electrical properties was revealed soon after CaM discovery through the genetic study of the avoidance response in Paramecium tetraurelia [7]. Paramecium is a unicellular eukaryotic organism uniformly covered with simple cilia that propels the cell in a spiral movement. When an obstacle is encountered or a stimulus is received, Paramecium swims backwards for about one second, before resuming its forward progress. In the 1970-90s of the past century, genetic variants that differed in their "avoiding reaction" were isolated, some underreacting and others overreacting [7]. Functional analysis underscored that the basis of such contrasting responses were deficiencies on a $\mathrm{Na}^{+}$inward current in the first case, or a deficit in a $\mathrm{K}^{+}$outward current for the overreacting variants. Interestingly, both currents are $\mathrm{Ca}^{2+}$-dependent and genetic analysis demonstrated that defects on the sole CaM gene in Paramecium were responsible for both phenotypes [8]. Thus, mutations in the same CaM gene result in opposing behavioral responses. How is that possible?

$\mathrm{CaM}$ is one of the most conserved proteins in evolution, with a sequence of 148 amino acids that is identical in all vertebrates (the first methionine is lost in the mature protein). It is encoded by three independent genes (CALM1-3) in humans, all translating identical CaM sequences. It is composed of four $\mathrm{Ca}^{2+}$-binding EF-hands, and each contains a helix-loop-helix motif with a central acidic loop of 12 residues for $\mathrm{Ca}^{2+}$ coordination via at least six oxygen atoms (Figure 1). The EF-hands are structurally organized in globular pairs forming the $\mathrm{N}$ - and $\mathrm{C}$ - terminal lobes that fold independently. Although both lobes probably appeared as a result of a gene duplication and are very similar in sequence and structure, the affinity of the C-terminal lobe is one order of magnitude higher than that of the $\mathrm{N}$-terminal lobe [9]. The EF-hands can adopt any of three conformations, open, semi-open and closed. The angles between the lobes and within the helix-loop-helix EF-hand open upon $\mathrm{Ca}^{2+}$ binding, exposing patches of hydrophobic amino acids. Whereas the interhand angle differs when loaded with $\mathrm{Ca}^{2+}$ in the C-lobe, such a conformational change is not observed for the N-lobe [10]. Both apo$\left(\mathrm{Ca}^{2+}\right.$-free $)$ and holo-CaM $\left(\mathrm{Ca}^{2+}\right.$-loaded $)$ can bind and regulate target proteins [11]. The CaM-binding domains (CaMBD) are usually amphipathic helical structures rich in hydrophobic and basic residues. The flexibility of the abundant methionine side chains confers another level of plasticity, enabling $\mathrm{CaM}$ to adapt to many target molecules and to display diverse regulation mechanisms in response to different $\mathrm{Ca}^{2+}$ levels [12]. CaM conformation also changes in the presence of target proteins, resulting in a sophisticated interplay between $\mathrm{Ca}^{2+}$ and target affinities: $\mathrm{Ca}^{2+}$ affinity of each lobe increases or decreases when $\mathrm{CaM}$ engages with a target, and the affinity for some targets increases when loaded with $\mathrm{Ca}^{2+}$, but for others, it decreases. For instance, the affinity of the $\mathrm{N}$-lobe for $\mathrm{Ca}^{2+}$ is higher than that of the C-lobe when engaged with voltage-gated potassium channels type $7\left(\mathrm{~K}_{\mathrm{V}} 7\right)$, whereas $\mathrm{Ca}^{2+}$ does not bind to the $\mathrm{C}$-lobe when $\mathrm{CaM}$ is engaged with some small conductance calcium-activated potassium (SK) channel variants. In other words, the $\mathrm{N}$-lobe becomes insensitive to $\mathrm{Ca}^{2+}$ oscillations when coupled to $\mathrm{K}_{\mathrm{V}} 7$ channels, whereas the $\mathrm{C}$-lobe becomes indifferent to $\mathrm{Ca}^{2+}$ when coupled to SK2 channels. When the $\mathrm{C}$-lobe is loaded with $\mathrm{Ca}^{2+}$, the strength of $\mathrm{CaM}$ binding to $\mathrm{K}_{\mathrm{V}} 7$ channels decrease, whereas when the N-lobe is loaded with $\mathrm{Ca}^{2+}$, the affinity for SK channels increases [13-17]. Our understanding of CaM function is limited, and anticipating the magnitude and direction of the changes on $\mathrm{Ca}^{2+}$ affinities prompted by the target and mutations remains a challenge, even knowing the structure of the complex at atomic resolution. As a general rule, the C-lobe plays a predominant role in target recognition under resting low $\mathrm{Ca}^{2+}$ conditions, and often the interaction between the target and the C-lobe weakens, whereas the binding to the $\mathrm{N}$-lobe becomes stronger when each lobe becomes loaded with $\mathrm{Ca}^{2+}[10]$. 

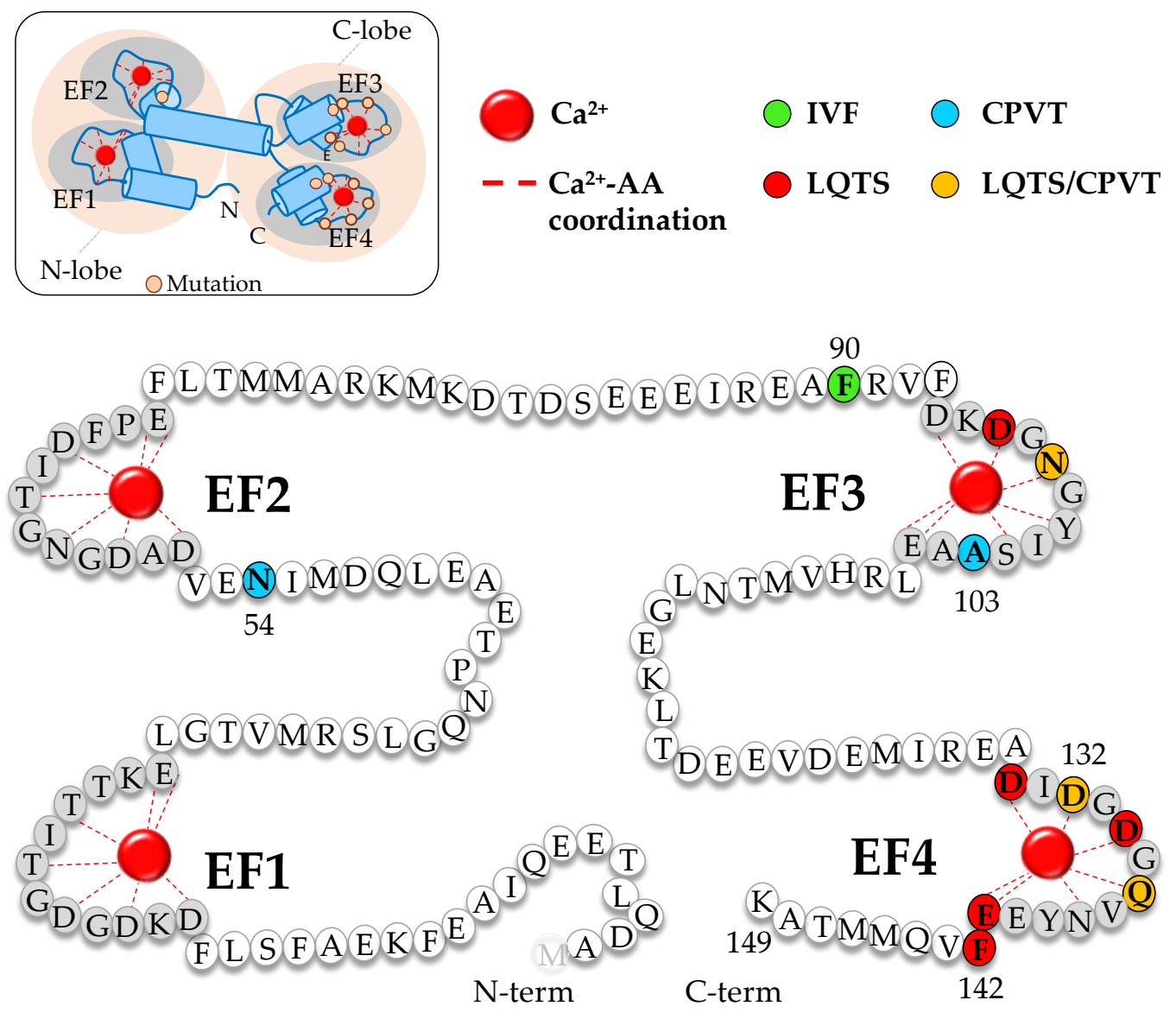

Figure 1. Location of the different mutations in calmodulinopathies. Top left panel: schematic representation of the structure of $\mathrm{CaM}$ showing $\mathrm{Ca}^{2+}$ coordination and mutations found in calmodulinopathies. The grey areas highlight the EF-hands shown in the main panel. Disease-associated residues are colored in green (IVF: idiopathic ventricular fibrillation), blue (CPVT: catecholaminergic polymorphic ventricular tachycardia), red (LQTS: long QT syndrome) and orange (both: LQTS/BrS) in the CaM sequence. The $\mathrm{Ca}^{2+}$-binding loop of each EF-hand is emphasized with a grey background.

The Paramecium genetic variants revealed a functional bipartition in which the $\mathrm{N}$ - and C-lobes have separate missions [18]. Mutations in the C-lobe impaired the $\mathrm{Ca}^{2+}$-dependent activation of a $\mathrm{K}^{+}$outward current, whereas mutations located in the N-lobe disrupted a $\mathrm{Na}^{+}$inward current. These studies underscored the importance of CaM in membrane electrogenesis. The possibility that alterations on the activity of ion channels due to mutations in different lobes of CaM could alter human physiology was corroborated in 2012 [19], which is remarkable given that defects in just one of the six alleles can cause disease. The descriptions of the pathological consequences of mutations in CALM genes have focused on its cardiac manifestations [20] (Figure 1).

\section{Cardiac Calmodulinopathies}

Sudden cardiac death (SCD) is the main cause of death in the western countries [21]. Multiple and collaborative causes—-such as myocardial infarction, coronary ischemia, endocrine diseases-contribute to SCD in adults. All these alterations increase the susceptibility to lethal ventricular arrhythmias. However, in young people (infants, children, and adolescents) the cause of SCD is more often genetic. Many gene alterations that predispose to ventricular lethal arrhythmias have been described, which include mutations in the main cardiac $\mathrm{Na}^{+}, \mathrm{Ca}^{2+}$, and $\mathrm{K}^{+}$channels [22], and mutations in other regulatory proteins such as ankyrin [23], caveolin [24], AKAP [25] and, more recently, CaM [19,26]. 
CaM regulates almost every cardiac ion channel, either by direct protein-protein interactions or indirectly through CaM-kinase II $[27,28]$. Thus, any alteration in CaM expression or function can derange the electrical behavior of the heart and induce arrhythmia or SCD [29,30]. The most recently described arrhythmic syndromes associated to mutations in CaM have been named "Calmodulinopathies" [31-33]. Pathological variants on every CALM gene have been discovered, and some have been isolated from different genes (e.g., CALM1-D130G, CALM2-D130G and CALM3-D130G; CALM1-N98S and CALM2-N98S, or CALM1-F142L and CALM3-F142L [34,35]). Nearly all of the identified CaM mutations impair $\mathrm{Ca}^{2+}$ binding, but little is known on how they affect the physical interaction with many relevant cardiac or neuronal ion channels (see below). Except one (N54I), all other seventeen amino acid replacements so far described are located in the C-lobe and connected with different cardiac dysfunctions, some associated with sudden cardiac arrest following exercise or emotion [35] (Figure 1). Some mutations have been structurally analyzed, and found to cause variable conformational changes of the whole C-lobe [36]. Mutations in CaM can be lethal at very early ages, and this can be a possible reason for the low prevalence of these calmodulinopathies. In fact, only 30 patients have been described carrying CALM mutations, where 20 were de novo mutations and only three inherited (N54I, F90L and A103V) [32]. The redundant nature of the CALM genes implies very strong pressure to conserve the identity of the two lobes. Perhaps most mutations in the N-lobe are not compatible with human life, explaining that only one pathological variant has been detected in this lobe until now. Interestingly, the only mutation found in the N-lobe, N54I, has relatively minor effects on CaM properties. The clinical phenotypes include Long QT Syndrome (LQTS), Catecholaminergic polymorphic ventricular tachycardia (CPVT), and idiopathic ventricular fibrillation (IVF) [20,33].

Excitation-contraction coupling (ECC) in cardiac muscle is initiated by activation of L-type voltage-gated $\mathrm{Ca}^{2+}$ channels $(\mathrm{Ca})$. $\mathrm{Ca}^{2+}$ entry through these channels causes the opening of cardiac ryanodine receptor ion channels (RyR2) promoting a massive $\mathrm{Ca}^{2+}$ release $\left(\mathrm{Ca}^{2+}\right.$-activated $\mathrm{Ca}^{2+}$-release) from the sarcoplasmic reticulum (SR) that initiates muscle contraction. The subsequent $\mathrm{Ca}^{2+}$ sequestration back into the SR by the ATPase-associated type-2a pump SERCA2a leads to muscle relaxation. $\mathrm{Na}^{+}$entry through $\mathrm{Na}^{+}$channels results in electrical excitation, thereby initiating ECC. The $\mathrm{Na}^{+}-\mathrm{Ca}^{2+}$ exchanger (NCX), on the other hand, electrogenically exchanges $1 \mathrm{Ca}^{2+}$ ion for $3 \mathrm{Na}^{+}$ ions, creating a direct link between $\mathrm{Na}^{+}$influx and $\mathrm{Ca}^{2+}$ cycling [37]. Generally, dysregulation of $\mathrm{Ca}^{2+}$ handling in the SR underlies CPVT, whereas LQTS involves malfunction of ion channels at the sarcolemma. The activity of all components implicated in the maintenance of $\mathrm{Ca}^{2+}$ homeostasis must be fine-tuned and orchestrated for appropriate heart contraction and rhythm.

The main repolarizing currents in the human heart are the transient outward $\left(\mathrm{I}_{\mathrm{to}}\right)$, the rapid delayed rectifier $\left(\mathrm{I}_{\mathrm{Kr}}\right)$ and the slow delayed rectifier $\left(\mathrm{I}_{\mathrm{Ks}}\right) \mathrm{K}^{+}$currents, carried through the $\mathrm{K}_{\mathrm{V}} 4.3$, $\mathrm{K}_{\mathrm{V}} 11.1$ or hERG and $\mathrm{K}_{\mathrm{V}} 7.1$ channels, respectively $[22,38]$. All these channels have been proposed to be modulated in some way by CaM. However, the hERG channel sequence has no known putative CaM binding motifs and the activation of either CaM or CaMKII have no effects on $\mathrm{I}_{\mathrm{Kr}}$ amplitude or kinetics $[39,40]$. Besides, the reported effects of CaM on the $\mathrm{I}_{\text {to }}$ amplitude or kinetics are mediated by changes in the activity of $\mathrm{Ca}^{2+}-\mathrm{CaM}$-dependent enzymes, including $\mathrm{Ca}^{2+} / \mathrm{CaMKII}[28,41]$. In conclusion, the only cardiac voltage-gated $\mathrm{K}^{+}$channels directly modulated by CaM seem to be $\mathrm{K}_{\mathrm{V}} 7.1$ channels. This modulation will be more extensively described in Section 7.

\section{Cardiac Ryanodine Receptors}

CPVT is most commonly caused by gain-of-function RyR2 mutations with excessive $\mathrm{Ca}^{2+}$ release [42,43] or mutations affecting RyR2-binding proteins [19,44], which lead to spontaneous opening and $\mathrm{Ca}^{2+}$ waves that trigger membrane depolarization. CPVT is an inherited disorder characterized by episodic syncope and/or sudden cardiac arrest during exercise or acute emotion in individuals without structural cardiac abnormalities that is suspected to cause a substantial number of SDCs in young individuals. RyR2 channels are equipped with two built-in $\mathrm{Ca}^{2+}$-binding EF-hands. 
The EF-hands of RyR respond to $\mathrm{Ca}^{2+}$ and mediate the gating of its $\mathrm{Ca}^{2+}$ channel. Thus, the presence of an external $\mathrm{Ca}^{2+}$ sensor is somehow redundant, and CaM plays a modulatory role [45]. CaM has a differential inhibitory effect on RyR2 channel activity at low and high free $\mathrm{Ca}^{2+}$ concentration [33]. In a CPVT RyR2 mutant mouse model carrying a point mutation (R2474S), the interaction with CaM upon PKA stimulation is altered [46]. Since CaM binds and regulates RyR2, it has been assumed that is the disruption of this particular interaction which leads to CPVT for the relevant CALM mutants. However, studies in mice models are difficult to reconcile with this view (see below).

RyR2 channels are huge homotetrameric structures exceeding 2 million Daltons in molecular weight composed of many regulatory sub-domains. Mutagenesis analysis indicates that both apo-CaM and holo-CaM binds to a site comprised by residues 3580-3609 of mouse RyR2. Most of the mutations responsible for different cardiac diseases are clustered in the N-terminus, central and C-terminal regions of the RyR2 primary sequence, and no mutations in the CaMBD linked to disease have yet been reported [43]. Two mice models that disrupt the CaMBD can bring some light on this issue. A knock-in carrying a triple mutation (W3587A, L3591D, and F3603A) interrupts direct CaM binding [47], but, surprisingly there are no major cardiac disturbances in heterozygosis, and no clear signs of CPVT even in homozygosis. Instead, the animals suffer cardiac hypertrophy and early death in homozygosis. A more focused model carrying single RyR2 amino acid substitution (L3591D) perturbs the CaM interaction at low $\mathrm{Ca}^{2+}$ levels, but little functional effect at higher systolic concentrations has been noted. Relatively minor cardiac disturbances have been described for these mice [48]. Thus, perturbations on the RyR2 CaMBD do not recapitulate the consequences of CPVT-causing CALM mutations. Alternatively, the product of those CALM genes may alter RyR2 function indirectly through other targets, including voltage-dependent $\mathrm{K}^{+}, \mathrm{Na}^{+}$, and $\mathrm{Ca}^{2+}$ ion channels.

\section{Cardiac Voltage-Gated Calcium Channels}

The arrangement of proteins within biological systems into macromolecular complexes and nanodomains is critical for function. RyR2 channels are organized in the cardiac dyad, a specialized signaling hub responsible of cardiac contraction. Classically, it consists of groups of L-type Ca 1.2 channels located in the transverse tubules closely apposed (10-12 nm) across the dyadic cleft to clusters of RyR2 channels on the SR membrane [49]. It is known that proteins in close proximity influence each other's function. CaM favors the formation of $\mathrm{Ca}_{\mathrm{v}} 1.2$ clusters that cause concerted activation, and this cooperative gating generates zones of high $\mathrm{Ca}^{2+}$ influx that amplify the $\mathrm{Ca}^{2+}$ signal, an amplification that appears to play a fundamental role in cardiac ECC [50]. These channels are regulated by $\mathrm{Ca}^{2+}$-dependent inactivation (CDI), an important feedback system required for $\mathrm{Ca}^{2+}$ homeostasis [33]. For both processes, CDI and cooperative gating, the CaM C-lobe plays a crucial role. Indeed, CDI reduction can lead to LQTS [51]. Remarkably, many pathological CALM mutations cause LQTS, and about half of those are reported to manifest also CPVT [20]. LQTS is characterized by a prolongation and/or distortion of the cardiac action potential, and thus the QT interval and T-wave, resulting in a prolonged repolarization. Mutations in any of 17 genes can cause LQTS, which include, among others, voltage-dependent $\mathrm{K}^{+}, \mathrm{Na}^{+}$, and $\mathrm{Ca}^{2+}$ channels, and ion channel accessory subunits [52].

A study using human induced pluripotent stem cell-derived cardiomyocytes (hiPSC-CM) from a symptomatic carrier of the CALM1-F142L mutation revealed alterations of CDI and a reduction in the persistent $\mathrm{Na}^{+}$current, with unremarkable alterations on CaM-regulated voltage-dependent $\mathrm{K}^{+}$ currents [53]. Other LQTS-causing mutations (D96V, D130G, and F142L) have been found to disrupt CDI in heterologous expression systems, whereas CaM mutants related to CPVT (N54I and N98S) exhibited little or no effect on CDI [51]. The N98S CaM mutant is capable of causing either CPVT [19], LQTS [54] or both [36], suggesting a critical interplay between the action on multiple targets and, perhaps, differing CaM expression levels among patients [51]. There is a marked increase in affinity between CaM and the CaMBD of $\mathrm{Ca}_{\mathrm{V}} 1.2$ channels for the F142L mutant under low $\mathrm{Ca}^{2+}$ conditions, consistent with the dominant effect of this mutation [36,51]. However, such an increase in binding affinity is not observed for other mutants. In fact, when mutant and wild type CaM are expressed in 
ratios that approach genetic balance, which should reduce the fraction of channels with pre-associated CaM variants, little or no effect on CDI is revealed for some mutants [51]. Thus, although the correlation between CDI and LQTS is remarkable, additional mechanisms should also be considered, such as the impact on channel clustering and in other targets, as well as integration of the signal at tissue and organism level.

The cardiac $\mathrm{Ca}^{2+}$ channel macromolecular complex is composed by four subunits arranged in a 1:1:1:1 stoichiometry: $\alpha 1(170 \mathrm{kDa}), \alpha 2(150 \mathrm{kDa}), \delta(17-25 \mathrm{kDa})$, and $\beta(52 \mathrm{kDa})$. The primary structure of the pore-forming $\alpha 1$ subunit, encoded by the CACNA1C gene, is composed of four homologous repeats $\left(D_{I}-D_{I V}\right)$, each of which consists of six transmembrane segments (S1-S6) linked by variable cytoplasmic loops (Figure 2). CDI is intimately related to a single CaM molecule tethered to the central C-terminal IQ site [55]. CDI requires CaM pre-association to the channel under low resting $\mathrm{Ca}^{2+}$ conditions. A conformational change upon $\mathrm{Ca}^{2+}$ binding is transmitted to the channel to impose inactivation. It has been proposed that this pre-association of the C-lobe of apo-CaM is required to amplify the action of a limited fraction of pathological CaM molecules, and, thus, molecules like calcineurin and CaM-kinase II may play little role in LQTS [51]. The IQ motif is a $\sim 11$ amino acids long sequence (IQxx $\Phi$ RxxxxR, where $\Phi$ is a bulky hydrophobic residue, see Figure 3) that represents perhaps the most recognizable apo-CaM binding site that interacts with the C-lobe. Upon loading the C-lobe with $\mathrm{Ca}^{2+}$, the interaction with the IQ motif generally becomes weaker. The term 'IQ' refers to the first two amino acids: isoleucine (commonly) and glutamine (almost invariably) [56]. Most other, but not all, CaM binding sequences can be discovered with the use of knowledge-based methods with a reasonable rate of success [57-59]. However, in spite of the large number of complexes resolved at atomic resolution, the orientation of the target, the changes in $\mathrm{Ca}^{2+}$ binding affinity and the conformational response is not yet predictable from the sequence alone, not even for the IQ motif [60].

L-type $\mathrm{Ca}_{\mathrm{V}}$ channels have an N-terminal and a C-terminal CaMBD (Figure 2). A component of CDI depends on the interaction of the $\mathrm{Ca}^{2+}$-loaded N-lobe with the $\mathrm{N}$-terminal spatial $\mathrm{Ca}^{2+}$ transforming element (NSCaTE) region located in the N-terminal domain between residues 47 and 68 of the channel [61]. A mutation linked to Brugada Syndrome (BrS) located in the N-terminal region (A39V), upstream of the NSCaTE domain, may interfere with N-lobe-dependent CDI [62]. BrS is an inherited cardiac arrhythmic syndrome associated with high risk of ventricular fibrillation and SDC in the absence of structural abnormalities [63]. Alternatively, the pathological manifestation of the A39V variant may be a consequence of general misfolding, since the mutated channels are retained at the endoplasmic reticulum, with gross changes in cellular morphology and a dramatic reduction in current density in CHO-K1 cells [64]. 
A

$\mathrm{Ca}_{\mathrm{v}} 1$ channels

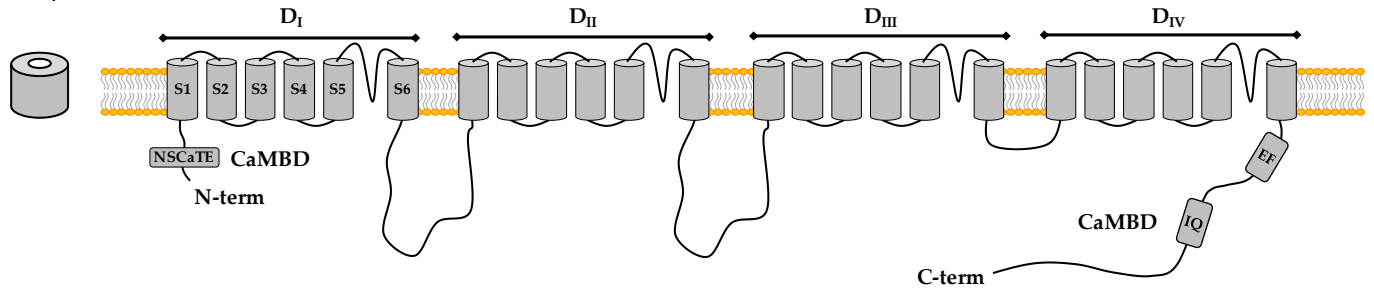

B

$\mathrm{Na}_{\mathrm{V}} 1$ channels

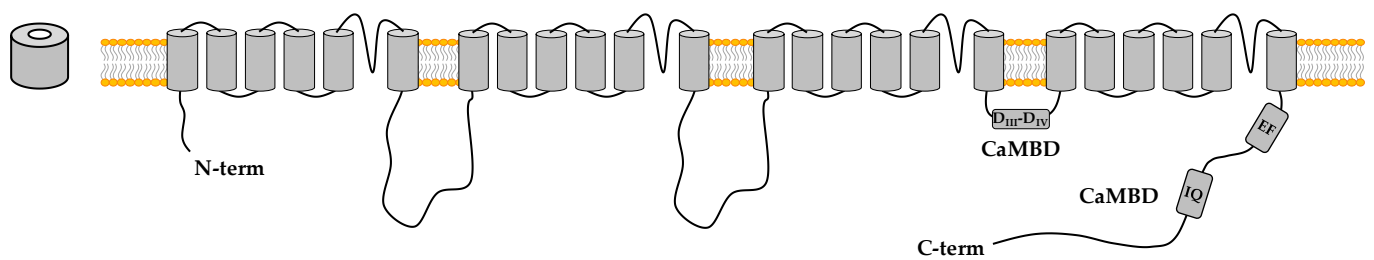

C

$\mathrm{K}_{\mathrm{V}} 7$ channels

D
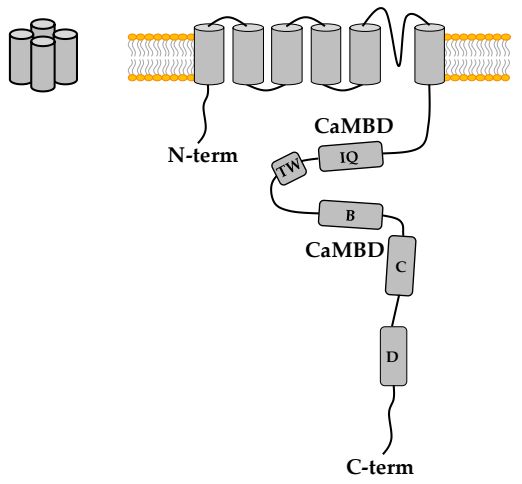

\section{$\mathrm{Ca}_{\mathrm{V}} \mathbf{1} / \mathrm{Na}_{\mathrm{v}} 1$ channels}
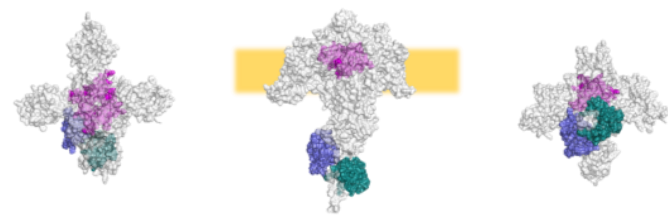

$\mathrm{K}_{\mathrm{V}} 7$ channels

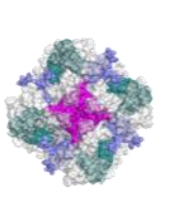

Top

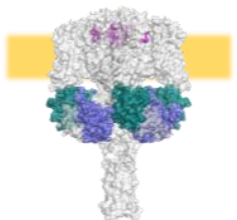

Lateral

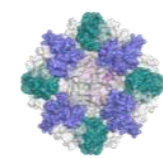

Intracellular

view

Figure 2. Topology of $\mathrm{Ca}_{V} 1, \mathrm{Na}_{\mathrm{V}} 1$, and $\mathrm{K}_{V} 7$ channels. Schematic representation of $\mathrm{Ca}_{V} 1(\mathbf{A}), \mathrm{Na}_{\mathrm{V}} 1$ (B), and $K_{V} 7(C)$ channels. The functional assemblies are schematically represented on the left side. Note that $\mathrm{Ca}_{V} 1$ and $\mathrm{Na}_{V} 1$ channels are composed of four repeats within a single polypeptide, while four subunits are needed to form $\mathrm{K}_{V} 7$ channels. Homologous repeat domains $\left(\mathrm{D}_{\mathrm{I}}-\mathrm{D}_{\mathrm{IV}}\right)$; transmembrane segments (S1-S6); N-terminal spatial $\mathrm{Ca}^{2+}$ transforming element (NSCaTE), CaM Binding Domain (CaMBD), IQ motif, EF-hands, TW helix, helix B, helix C, and helix D are labeled. (D) Composite 3D structures of $\mathrm{Ca}_{V} 1 / \mathrm{Na}_{\mathrm{V}} 1$ channels (top panel; combining PDBs: 5GJW and 4DCK) and $\mathrm{K}_{\mathrm{V}} 7$ channels (bottom panel; PDBs: 5VMS and 3BJ4). The pore forming domain is colored in magenta, the CaM $\mathrm{N}$-lobe in blue and C-lobe in green. Transparency was set to $40 \%$, allowing the view of CaM from the top, and the pore from a lateral perspective. Note that in the presence of $\mathrm{Ca}^{2+}$, the N-lobe of CaM should be near the $\mathrm{N}$-terminal of the $\mathrm{Ca}_{\mathrm{V}}$ channels or the $\mathrm{D}_{\mathrm{III}}-\mathrm{D}_{\mathrm{IV}}$ linker for $\mathrm{Na}_{\mathrm{V}}$ channels after activation (not shown). The auxiliary $\beta$ subunits are not shown. Pymol 1.5 was used to render panel D. 

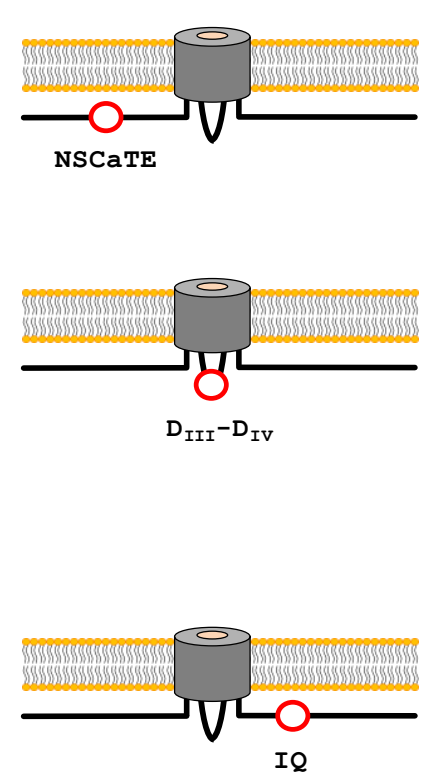

IQ

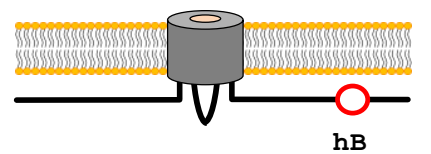

$\mathrm{K}_{\mathrm{V}} 7.1$

$\mathrm{K}_{\mathrm{V}} 7.2$

- BrS

- LQTS / BrS
EF-hand/ (C-Lobe?)

$\mathrm{N}$-Lobe

$\mathrm{Na}_{V} 1.2$ 1488-IFMTEEQKKYYNAMKKLGSKKPQKPIPRPANKFQGMVFDFVTKQVF-1533 $\mathrm{Na}_{V} 1.4$ 1310-I FMTEEQKKYYNAMKKLGSKKPQKP I PRPQNKIQGMVYDLVTKQAF-1355 $N_{V} 1.51485$-IFMTEEQKKYYNAMKKLGSKKPQKPIPRPLNKYQGFIFDIVTKQAF-1530 $\mathrm{Na}_{V} 1.6$ 1479-IFMTEEQKKYYNAMKKLGSKKPQKPIPRPLNKIQGIVEDFVTQ̊QA Site A Site B

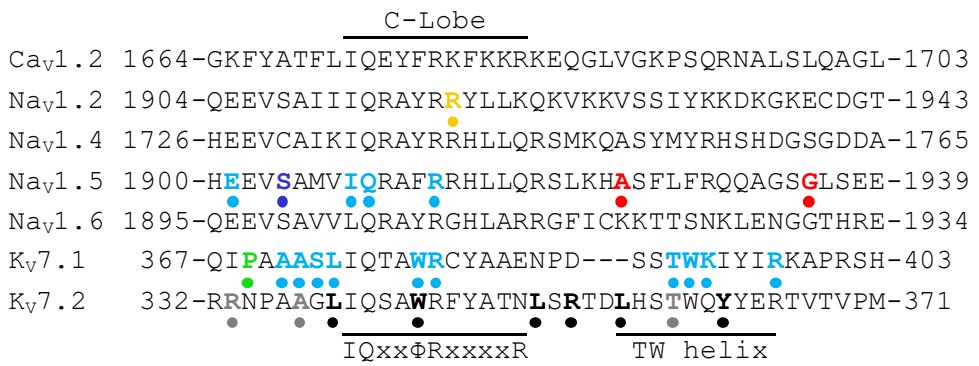

$$
\text { N-Lobe }
$$

503-ISQLREHHRATIKVIRRMQYFVAKKKFQQARKPYDVRD- 540 529-TEDLTPGLKVS IRAVCVMRFLVSKRKFKESLRPYDVMD- 566

Figure 3. Location of the different mutations found in $\mathrm{Ca}_{V} 1, \mathrm{Na}_{V} 1$, and $\mathrm{K}_{V} 7$ channel CaMBD that lead to channelopathies. Left: schematic overall location of different CaMBD (red circle). Note that $\mathrm{K}_{\mathrm{V}} 7$ channels have four IQ/helix A and helix B domains (See Figure 2). NSCaTE (N-terminal spatial $\mathrm{Ca}^{2+}$ transforming element) is only present in $\mathrm{Ca}_{\mathrm{V}} 1$ channels, $\mathrm{D}_{\mathrm{III}}-\mathrm{D}_{\mathrm{IV}}$ repeat domain linker CaMBD is only found in $\mathrm{Na}_{V} 1$ channels, the IQ motif (IQ) is present in all of them and helix B (hB) is only present in $\mathrm{K}_{\mathrm{V}} 7$ channels. Right: The IFM inactivation motif of $\mathrm{Na}_{\mathrm{V}}$ is boxed. The interacting CaM lobe or channel domain is indicated on top of the corresponding sequences. The location of the mutation and the disease linked to each mutation is indicated in the color scheme at the bottom. BrS: Brugada syndrome; LQTS: long QT syndrome; IGE: idiopathic generalized epilepsy; GF: gingival fibromatosis; EE: epileptic encephalopathy; BFNS: benign familial neonatal seizures.

\section{Cardiac Voltage-Gated Sodium Channels}

Whereas no channelopathies within the IQ motif of $\mathrm{Ca}^{2+}$ channels have been described, mutations at the equivalent site of voltage-gated sodium channels $\left(\mathrm{Na}_{\mathrm{V}}\right)$ have been linked to several excitability disorders $[65,66]$ (Table 1; Figure 3). Both $\mathrm{Na}_{\mathrm{V}}$ and $\mathrm{Ca}_{\mathrm{V}}$ channels present a similar architecture (Figure 2), which consists of a 24-transmembrane- $\alpha$-subunit (4 repeats domains), and differs in the auxiliary $\beta$ subunit $\left(\mathrm{Na}_{\mathrm{V}} \beta 1-4\right)$. These channels present an IQ CaMBD at the C-terminal domain preceded by a vestigial EF-hand-like domain [67]. Mutations in the IQ motif of $\mathrm{Na}_{\mathrm{v}} 1.5$ (R1897W, E1901Q, S1904L, Q1909R, R1913H, and A1924T) [68,69] result in BrS1, LQT3 or mixed syndromes (an overlap of BrS1/LQT3 [65,70,71], see Figure 3). Besides the IQ site, CaM binds in solution to two sites within a fragment with the sequence of the intracellular loop between repeats 3 ( $\mathrm{D}_{\text {III }}$ ) and 4 ( $\mathrm{D}_{\text {IV }}$ ) of $\mathrm{Na}^{+}$channels (Figure 2), an interaction that is postulated to be critical to modulate inactivation mediated by the IFM motif located at the very beginning of the $\mathrm{D}_{\mathrm{III}}-\mathrm{D}_{\mathrm{IV}}$ linker [72]. It has been suggested that, upon $\mathrm{Ca}^{2+}$ 
elevation, the IQ-bound CaM molecule is transferred to the $\mathrm{D}_{\mathrm{III}}-\mathrm{D}_{\mathrm{IV}}$ linker or bridge both sites after a $180^{\circ}$ re-orientation of the C-lobe around the IQ helix, so the N-lobe could reach alternate sites [60].

Table 1. Mutations in Nav1.5 channels influencing CaM binding. LQT3: long QT syndrome type 3; BrS: Brugada syndrome; IFM motif: inactivation motif; A $D_{\text {III }}-D_{I V}$ linker: A CaM binding domain within the $\mathrm{D}_{\mathrm{III}}-\mathrm{D}_{\mathrm{IV}}$ linker; B $\mathrm{D}_{\mathrm{III}}-\mathrm{D}_{\mathrm{IV}}$ linker: B CaM binding B domain within the $\mathrm{D}_{\mathrm{III}}-\mathrm{D}_{\mathrm{IV}}$ linker.

\begin{tabular}{|c|c|c|c|c|}
\hline Nav1.5 Mutation & Location & Interacting Site & Disease & Reference \\
\hline F1486L & IFM motif & / & LQT3 & [73] \\
\hline M1487L & IFM motif & / & LQT3 & [74] \\
\hline $\mathrm{T} 1488 \mathrm{R}$ & A D $D_{\text {III }}-D_{\text {IV linker }}$ & N-lobe & LQT3 & [74] \\
\hline E1489D & A D $D_{\text {III }}-D_{\text {IV }}$ linker & N-lobe & LQT3 & [74] \\
\hline K1493R & A D $D_{\text {III }}-D_{\text {IV linker }}$ & N-lobe & LQT3 & [74] \\
\hline Y1494N & A D $D_{\text {III }}-D_{\text {IV linker }}$ & N-lobe & $\mathrm{BrS}$ & [72] \\
\hline Y1495S & A D $\mathrm{D}_{\mathrm{III}}-\mathrm{D}_{\mathrm{IV}}$ linker & N-lobe & LQT3 & [73] \\
\hline M1498T & A D $\mathrm{DIII}_{\text {IIV linker }}$ & N-lobe & LQT3 & [73] \\
\hline L1501V & A $D_{\mathrm{III}}-\mathrm{D}_{\mathrm{IV}}$ linker & / & LQT3/BrS & [72] \\
\hline G1502S & A D $\mathrm{DIII}^{-\mathrm{D}_{\mathrm{IV}} \text { linker }}$ & / & $\mathrm{BrS}$ & [73] \\
\hline K1505N & D III-D IV linker & / & LQT3/BrS & [74] \\
\hline R1512W & $\mathrm{D}_{\mathrm{III}}-\mathrm{D}_{\mathrm{IV}}$ linker & / & $\mathrm{BrS}$ & [75] \\
\hline I1521K & B D $\mathrm{D}_{\mathrm{III}}-\mathrm{D}_{\mathrm{IV}}$ linker & EF hand/C-lobe & $\mathrm{BrS}$ & [72] \\
\hline V1525M & B D $\mathrm{III}-\mathrm{D}_{\mathrm{IV}}$ linker & EF hand/C-lobe & $\mathrm{BrS}$ & [72] \\
\hline K1527R & D ${ }_{\text {III }}-D_{\text {IV }}$ linker & / & $\mathrm{BrS}$ & [76] \\
\hline V1777M & Pre-EF hands & / & LQT3 & [73] \\
\hline $\mathrm{T} 1779 \mathrm{M}$ & Pre-EF hands & / & LQT3/BrS & [73] \\
\hline E1784K & EF hands & B D $D_{\text {III }}-D_{\text {IV }}$ linker & LQT3 & [73] \\
\hline L1786Q & EF hands & B D $D_{\text {III }}-D_{\text {IV }}$ linker & LQT3/BrS & [73] \\
\hline S1787N & EF hands & B D $D_{\text {III }}-D_{\text {IV }}$ linker & LQT3 & [73] \\
\hline D1790G & EF hands & B D $\mathrm{III}-\mathrm{D}_{\mathrm{IV}}$ linker & LQT3/BrS & [66] \\
\hline Y1795InsD & EF hands & B D $D_{\text {III }}-D_{\text {IV }}$ linker & LQT3/BrS & [77] \\
\hline Y1795C & EF hands & B D $D_{\text {III }}-D_{\text {IV }}$ linker & LQT3 & [66] \\
\hline $\mathrm{D} 1819 \mathrm{~N}$ & EF hands & B D $\mathrm{III}-\mathrm{D}_{\mathrm{IV}}$ linker & LQT3 & [73] \\
\hline L1825P & EF hands & B D $D_{\text {III }}-D_{\text {IV }}$ linker & LQT3 & [77] \\
\hline $\mathrm{R} 1826 \mathrm{H}$ & EF hands & $\mathrm{B}_{\mathrm{III}}-\mathrm{D}_{\mathrm{IV}}$ linker & LQT3 & [77] \\
\hline Q1832E & EF hands & B D $D_{\text {III }}-D_{\text {IV }}$ linker & $\mathrm{BrS}$ & [77] \\
\hline$\widehat{\mathrm{D} 1839 \mathrm{G}}$ & EF hands & B D $D_{\text {III }}-D_{\text {IV }}$ linker & LQT3 & [73] \\
\hline H1849R & EF hands & B D $D_{\text {III }}-D_{\text {IV }}$ linker & LQT3 & [73] \\
\hline C1850S & EF hands & B D $D_{\text {III }}-D_{\text {IV }}$ linker & $\widehat{\mathrm{BrS}}$ & [73] \\
\hline V1861I & EF hands & B D $D_{\text {III }}-D_{\text {IV }}$ linker & $\mathrm{BrS}$ & [73] \\
\hline K1872N & EF hands & $\mathrm{B}_{\mathrm{III}}-\mathrm{D}_{\mathrm{IV}}$ linker & $\mathrm{BrS}$ & [73] \\
\hline M1875T & Pre-IQ motif & / & LQT3 & [73] \\
\hline R1897W & Pre-IQ motif & / & LQT3 & [78] \\
\hline E1901Q & Pre-IQ motif & / & LQT3 & [66] \\
\hline S1904L & Pre-IQ motif & / & LQT3/BrS & [74] \\
\hline Q1909R & IQ motif & C-lobe & LQT3 & [66] \\
\hline R1913H & IQ motif & C-lobe & LQT3 & [66] \\
\hline A1924T & Post-IQ motif & / & $\widehat{\mathrm{BrS}}$ & [71] \\
\hline G1935S & Post IQ motif & / & $\mathrm{BrS}$ & [74] \\
\hline
\end{tabular}

Recent cryo-EM single particle reconstitutions reveal that the vestigial EF-hand motif located after the last $\mathrm{S} 6$ transmembrane segment, just upstream of the IQ site, interacts with site A of the $\mathrm{D}_{\mathrm{III}}-\mathrm{D}_{\mathrm{IV}}$ linker $[79,80]$. In solution, the holo-C-lobe can bind to site B [72], and $\mathrm{Ca}^{2+}$-loaded CaM can interfere with the binding between the vestigial EF-hand and the $\mathrm{D}_{\mathrm{III}}-\mathrm{D}_{\mathrm{IV}}$ linker. As pointed out by Van Petegem and collaborators, whether holo-CaM can modulate this interaction in the full channel remains to be found [77].

Mutations within the $\mathrm{D}_{\mathrm{III}}-\mathrm{D}_{\mathrm{IV}}$ linker have also been associated with the genetic arrhythmia syndromes BrS and LQTS [74] (Table 1; Figure 3). The consequent reduction in CaM binding results in increased persistent $\mathrm{Na}^{+}$current or slower inactivation $[66,81]$. However, not every disease-causing 
mutation in the $\mathrm{D}_{\mathrm{III}}-\mathrm{D}_{\mathrm{IV}}$ linker leads to a reduction on CaM binding [72]. Another cluster of mutations linked to BrS and LQT is located in the EF-hand like domain (D1790G, Y1795InsD, L1825P, and R1826H) [36,77] (Table 1; Figure 3).

Somehow resembling the role of $\mathrm{CaM}$ in cluster formation for $\mathrm{Ca}^{2+}$ channels, it has been suggested that $\mathrm{CaM}$ may favor the formation of $\mathrm{Na}_{\mathrm{V}}$ dimers [66,82]. The existence of such $\mathrm{Na}^{+}$channel dimers has received strong experimental support, although the C-terminal region that harbors the CaMBD is not required for dimerization. The protein 14-3-3, instead of CaM, appears to play a critical role for functionally coupling adjacent $\mathrm{Na}^{+}$channels [83].

\section{Cardiac Voltage-Gated $\mathrm{K}_{\mathrm{V}} 7.1$ Potassium Channels}

$\mathrm{K}_{\mathrm{V}} 7.1$ is another CaM binding channel involved in LQTS (Table 2). $\mathrm{K}_{\mathrm{V}} 7.1$ in association with the auxiliary $\beta$ subunit minK (currently referred to as KCNE1) represents the molecular substrate for the slow delayed rectifier potassium current $\left(\mathrm{I}_{\mathrm{Ks}}\right)$ [22]. This current plays a critical role in repolarization of the cardiac action potential. The most common genetic arrhythmic syndromes are caused by mutations in the KCNQ1 gene, the gene encoding $\mathrm{K}_{\mathrm{V}} 7.1$, underlying $30-35 \%$ of all LQTS subtypes (Figure 3). Any loss-of-function or gain-of-function mutation in this gene can induce severe arrhythmic phenotypes such as LQT1, Romano-Ward, Lange-Nielsen, or short QT syndromes (SQTS). In addition, mutations in the KCNE1 gene, which encodes minK, can cause the same arrhythmic syndromes [22]. The channel is the result of the assembly of four subunits with architecture similar to that of each repeat found in $\mathrm{Na}_{\mathrm{V}}$ or $\mathrm{Ca}_{\mathrm{V}}$ channels. CaM interacts with two non-continuous segments, named helix A and helix B, located after the last transmembrane segment S6 [84-86] (Figure 2). Helix A contains an IQ site that, like in $\mathrm{Na}_{\mathrm{V}}$ and $\mathrm{Ca}_{\mathrm{V}}$ channels, interacts with the CaM C-lobe under low $\mathrm{Ca}^{2+}$ resting levels. Because $\mathrm{K}_{\mathrm{V}} 7.1$ channels are tetramers, four CaM molecules interact simultaneously with the channel, forming a CaM ring just underneath the membrane [87]. Mutations causing LQT1 that interfere with binding to CaM, disrupt channel trafficking, assembly, gating or both [85,86]. Most mutations localize into helix B (M520R, K526E, P535T, and R539W [85,88,89]), and other known pathological mutation map in the IQ motif (i.e., W392R [86], Table 1; Figure 3). There is general agreement that the $\mathrm{N}$-lobe anchors CaM to helix B, maintaining EF1 and EF2 hands loaded with $\mathrm{Ca}^{2+}$ all the time under physiological conditions (this represents a remarkable example of a change in $\mathrm{Ca}^{2+}$ binding affinity upon target engagement: the affinity for $\mathrm{Ca}^{2+}$ is larger for the $\mathrm{N}$-lobe than for the $\mathrm{C}$-lobe when $\mathrm{CaM}$ clamps $\mathrm{K}_{\mathrm{V}} 7$ channels), and the C-lobe transmits $\mathrm{Ca}^{2+}$ signals to the pore $[15,16,90,91]$.

Table 2. Mutations in $\mathrm{K}_{\mathrm{V}} 7.1$ channels influencing CaM binding. GF: gingival fibromatosis; LQT1: long QT syndrome type 1; hA: helix A; hTW: TW helix; hB: helix B.

\begin{tabular}{ccccc}
\hline KV7.1 Mutation & Location & Interacting Site & Disease & Reference \\
\hline P369L & hA & C-lobe & GF & {$[92]$} \\
A371T & hA & C-lobe & LQT1 & {$[73]$} \\
A372D & hA & C-lobe & LQT1 & {$[73]$} \\
S373P & hA & C-lobe & LQT1 & {$[73]$} \\
L374H & hA & C-lobe & LQT1 & {$[73]$} \\
W379S & hA & C-lobe & LQT1 & {$[73]$} \\
R380S & hA & C-lobe & LQT1 & {$[73]$} \\
S389Y & hTW & $/$ & LQT1 & {$[88]$} \\
T391I & hTW & $/$ & LQT1 & {$[73]$} \\
W392R & hTW & $/$ & LQT1 & {$[73]$} \\
K393M & hTW & $/$ & LQT1 & {$[73]$} \\
K393N & hTW & $/$ & LQT1 & {$[73]$} \\
R397N & hTW & $/$ & LQT1 & {$[73]$} \\
P448R & hTW-hB linker & $/$ & LQT1 & {$[73]$} \\
R451Q & hTW-hB linker & $/$ & LQT1 & {$[73]$} \\
R452W & hTW-hB linker & $/$ & LQT1 & {$[73]$} \\
\hline
\end{tabular}


Table 2. Cont.

\begin{tabular}{ccccc}
\hline KV$_{\mathbf{V}}$ 7.1 Mutation & Location & Interacting Site & Disease & Reference \\
\hline G460S & hTW-hB linker & $/$ & LQT1 & {$[73]$} \\
I517T & hB & N-lobe & LQT1 & {$[73]$} \\
R518G & hB & N-lobe & LQT1 & {$[73]$} \\
R518P & hB & N-lobe & LQT1 & {$[73]$} \\
R519C & hB & N-lobe & LQT1 & {$[73]$} \\
M520R & $h B$ & N-lobe & LQT1 & {$[73]$} \\
V524G & $h B$ & N-lobe & LQT1 & {$[73]$} \\
A525T & $h B$ & N-lobe & LQT1 & {$[93]$} \\
K526E & $h B$ & N-lobe & LQT1 & {$[89]$} \\
R533W & Post-hB & $/$ & LQT1 & {$[94]$} \\
P535T & Post-hB & $/$ & LQT1 & {$[73]$} \\
R539W & Post-hB & $/$ & LQT1 & {$[85]$} \\
\hline
\end{tabular}

The lipid molecule phosphatidylinositol 4,5-bisphosphate $\left(\mathrm{PIP}_{2}\right)$ is essential for $\mathrm{K}_{\mathrm{V}} 7.1$ function, and plays a critical role in coupling the voltage sensor to the gate of the pore. The auxiliary subunit KCNE1 causes a large (100 fold) increase in apparent affinity for $\mathrm{PIP}_{2}$, which leads to augmentation in current amplitude [95]. There are solid evidences for the formation of a ternary complex between PIP $_{2}$, $\mathrm{CaM}$, and $\mathrm{K}_{\mathrm{V}} 7.1$ channels. Interestingly, disruption of this complex by the LQT1 mutation K526E leads to compromised $\mathrm{I}_{\mathrm{Ks}}$ channel gating [89].

At the bench, the role of $\mathrm{Ca}^{2+}$ binding to each EF-hand is often addressed by testing mutants in which the first aspartate on the $\mathrm{Ca}^{2+}$ binding loop is mutated to alanine. Depending on the hands affected, those mutants are named CaM1, CaM2. It has been found that overexpression of $\mathrm{CaM} 3$ or CaM4 affects the voltage-dependency of $\mathrm{K}_{\mathrm{V}} 7.1$ currents, causing a rightward shift in the current-voltage relationship (stronger depolarizations are required to open the channel), whereas $\mathrm{Ca}^{2+}$ leads to a displacement to the left (i.e. facilitates opening in response to depolarization) $[16,90]$, suggesting that $\mathrm{Ca}^{2+}$-loading of the $\mathrm{C}$-lobe is somehow transmitted to the voltage sensor of the channel. Interestingly, a cryo-EM structure reveals a potential interaction between the $\mathrm{Ca}^{2+}$-binding loop of the EF3 hand of the C-lobe and the S2-S3 loop which is part of the voltage sensor [87]. Consistent with the effect of CaM3 and CaM4 mutants, the pathological N98S mutant, that also disrupts $\mathrm{Ca}^{2+}$ binding to EF3, causes a shift in the $K_{V} 7.1$ voltage dependence of activation in the positive direction [87]. Given the similar impact on voltage-dependence caused by CaM3 and CaM4, it can be anticipated that those pathological mutations that disrupt $\mathrm{Ca}^{2+}$ binding to EF4 hand will also cause a shift on the voltage-dependence of $\mathrm{K}_{\mathrm{V}} 7$ channels. Furthermore, these results suggest an intimate connection between EF3 and EF4 hands, or that the $\mathrm{K}_{\mathrm{V}} 7.1 \mathrm{AB} / \mathrm{CaM}$ complex may reorient to allow the EF4 hand to directly interact with the S2-S3 loop.

Recently, a mutation in the IQ site of the CaMBD of $\mathrm{K}_{\mathrm{V}} 7.1$ channels has been linked to gingival fibromatosis (GF), a disease related to human growth [92] (Table 2; Figure 3). This mutation (P369L), that does not compromise appreciably the integrity of the $\mathrm{K}_{\mathrm{V}} 7.1 \_\mathrm{AB} / \mathrm{CaM}$ complex, leads to increased current levels, and is associated with reduced pituitary hormone secretion from AtT-20 cells. Another mutation linked to GF, R116L, is located in the N-terminal region, outside the CaMBD, and also causes an increase in current levels [92]. Interestingly, the $\mathrm{N}$-terminal region of $\mathrm{K}_{\mathrm{V}} 7.2$ channels is the site of engagement of protein phosphatase 1 , which regulates the phoshorylation state of resident CaM. Mutations at the N-terminus that disrupt binding of $\mathrm{K}_{\mathrm{V}} 7.2$ to this phosphatase cause an increase in current density $[96,97]$. However, it is not known if protein phosphatase 1 or another phosphatase binds to sites at the N-terminal domain of $\mathrm{K}_{\mathrm{V}} 7.1$ channels. Of note, no major cardiac effects have been described for these GF patients [92]. 


\section{Neuronal channels}

Besides the cardiac consequences of mutations in CALM genes described above, neurological disturbances have been also noted [26]. Although possible brain injury secondary to cardiac arrest during early life has been pointed out as the most probable cause [26], the neurodevelopmental and excitability alterations resemble those prompted by mutations at the CaMBD of neuronal channels (see below). Indeed, neuronal $\mathrm{K}_{\mathrm{V}} 7$ channels and neuronal $\mathrm{Na}_{\mathrm{V}}$ channels have a perfectly recognizable and functional IQ binding motif, and neurological disorders linked to mutations on this site have been described for $\mathrm{Na}_{\mathrm{V}} 1.2$ and $\mathrm{K}_{\mathrm{V}} 7.2$ channels, including epileptic syndromes, characterized by seizures as a result of excessive and abnormal neuronal activity (Tables 3 and 4; Figure 3). The mutation R1918H in $\mathrm{Na}_{V} 1.2$ associated to epilepsy [98] may disrupt the interaction with the linker between the C-and N-lobes observed in some crystal structures [99]. The H1853R and R1918H mutations provoke an increase of the persistent current, and CaM overexpression reduces that current to normal values, suggesting that these mutations cause a decrease in CaM binding affinity [66] (Table 3; Figure 3).

Table 3. Mutations in $\mathrm{Na}_{\mathrm{V}} 1.2$ channels influencing CaM binding. OS: Ohtahara syndrome; IGE: idiopathic generalized epilepsy.

\begin{tabular}{ccccc}
\hline Nav1.2 Mutation & Location & Interacting Site & Disease & Reference \\
\hline H1853R & Pre-IQ motif & $/$ & OS & {$[66]$} \\
R1918H & IQ motif & C-lobe & IGE & {$[66]$} \\
\hline
\end{tabular}

The neuronal homologs of $\mathrm{K}_{\mathrm{V}} 7.1$ channels, $\mathrm{K}_{\mathrm{V}} 7.2$ and $\mathrm{K}_{\mathrm{V}} 7.3$, combine to form M-channels, which are critical for the control of excitability. These subunits were discovered searching for the genetic basis of benign familial neonatal seizures (BFNS), a rare autosomal-dominant idiopathic epilepsy of the newborn [100-102]. Later, it was found that mutations on the KCNQ2 gene, which encodes $\mathrm{K}_{\mathrm{V}} 7.2$ subunits, also leads to more severe encephalopathic epilepsy, with poor prognosis (Table 4; Figure 3). This disease is now named KCNQ2-encephalopathy or IEE7. EE is a severe brain disorder of early age that manifest with seizures, cognitive, behavioral, and neurological deficits and sometimes early death $[103,104]$.

Table 4. Mutations in $\mathrm{K}_{\mathrm{V}} 7.2$ channels influencing CaM binding. EE: epileptic encephalopathy; BFNS: benign familial neonatal seizures; hA: helix A; hTW: TW helix; hB: helix B; hD: helix D.

\begin{tabular}{|c|c|c|c|c|c|}
\hline \multicolumn{2}{|c|}{$K_{V} 7.2$ Mutation } & \multirow{2}{*}{ Location } & \multirow{2}{*}{$\begin{array}{c}\text { Interacting } \\
\text { Site }\end{array}$} & \multirow{2}{*}{ Location } & \multirow{2}{*}{ Reference } \\
\hline Isoform 1 & Isoform 3 & & & & \\
\hline R333Q & R333Q & Pre-hA & / & $\mathrm{EE}$ & [105] \\
\hline R333W & R333W & Pre-hA & / & $\mathrm{EE}$ & [106] \\
\hline A337G & A337G & hA & C-lobe & EE & [107] \\
\hline L339R & L339R & hA & C-lobe & BFNS & [108-111] \\
\hline W344R & W344R & $\mathrm{hA}$ & C-lobe & BFNS & [109] \\
\hline L351F & L351F & hA-hTW linker & / & BFNS & [109] \\
\hline L351V & L351V & hA-hTW linker & / & BFNS & [109] \\
\hline R353G & R353G & hA-hTW linker & / & BFNS & [108-111] \\
\hline L356V & L356V & hTW & / & BFNS & [107] \\
\hline T359K & T359K & hTW & / & EE & [112] \\
\hline Y362C & Y362C & hTW & / & BFNS & [109] \\
\hline M546V & M518V & $\mathrm{hB}$ & N-lobe & EE & {$[106,109]$} \\
\hline R547W & R519W & $\mathrm{hB}$ & N-lobe & $\mathrm{EE}$ & [107] \\
\hline K552T & K524T & $\mathrm{hB}$ & N-lobe & $\mathrm{EE}$ & [107] \\
\hline R553Q & R525Q & $\mathrm{hB}$ & N-lobe & $\mathrm{EE}$ & [107] \\
\hline
\end{tabular}


Table 4. Cont.

\begin{tabular}{|c|c|c|c|c|c|}
\hline \multicolumn{2}{|c|}{$\mathrm{K}_{\mathrm{V}} 7.2$ Mutation } & \multirow[b]{2}{*}{ Location } & \multirow{2}{*}{$\begin{array}{c}\text { Interacting } \\
\text { Site }\end{array}$} & \multirow[b]{2}{*}{ Location } & \multirow{2}{*}{ Reference } \\
\hline Isoform 1 & Isoform 3 & & & & \\
\hline $\mathrm{K} 554 \mathrm{~N}$ & $\mathrm{~K} 526 \mathrm{~N}$ & $\mathrm{hB}$ & N-lobe & $\mathrm{EE}$ & {$[105,106,113]$} \\
\hline K556E & $\mathrm{K} 528 \mathrm{E}$ & $\mathrm{hB}$ & N-lobe & $\mathrm{EE}$ & [107] \\
\hline R560W & R532W & hB & N-lobe & $\mathrm{EE}$ & [106] \\
\hline P561L & P533L & hB & N-lobe & $\mathrm{EE}$ & [107] \\
\hline D563N & D535N & $\mathrm{hB}$ & N-lobe & $\mathrm{EE}$ & [107] \\
\hline R581Q & R553Q & hB & N-lobe & $\mathrm{EE}$ & {$[106,109]$} \\
\hline $\mathrm{R} 581 \tilde{G}$ & R553 $\tilde{G}$ & hB & N-lobe & EE & [114] \\
\hline L637R & L609R & $\mathrm{hD}$ & N-lobe & BFNS & {$[115,116]$} \\
\hline
\end{tabular}

As for $\mathrm{K}_{\mathrm{V}} 7.1$ channels, CaM binding to helix $\mathrm{A}$ and helix $\mathrm{B}$ is critical for exiting the endoplasmic reticulum and affects assembly. In addition, mutations that alter $\mathrm{CaM}$ binding disrupt targeting of the channels to the axon initial segment $[111,117,118]$. Contrary to $\mathrm{I}_{\mathrm{Ks}}, \mathrm{Ca}^{2+}$ inhibits the M-current $[119,120]$. It is thought that, like for $\mathrm{Ca}_{\mathrm{V}}, \mathrm{Na}_{\mathrm{V}}$, and SK2 channels, the transduction mechanism involves two steps. The first step for these channels is anchoring the C-lobe to the IQ motif or its structural equivalent under resting $\mathrm{Ca}^{2+}$ conditions, thereby increasing the effective local concentration of the N-lobe near its target sequence. The second step is the engagement of the N-lobe with its corresponding binding site. After completion of the second step that requires $\mathrm{Ca}^{2+}, \mathrm{Ca}_{\mathrm{V}}$ channels inactivate or SK channels open the pore $[17,67]$. A similar two-step process is at work for $\mathrm{K}_{\mathrm{V}} 7.2$ channels, but the initial step takes place between the N-lobe and helix B. Formation of the N-lobe/helix B complex facilitates binding of the C-lobe to helix A located in the same or in another subunit $[14,116,121,122]$. The C-lobe transmits a gating signal when occupied with $\mathrm{Ca}^{2+}$, which either opens cardiac $\mathrm{K}_{\mathrm{V}} 7.1$ channels, or closes neuronal $\mathrm{K}_{\mathrm{V}} 7$ channels $[16,90,91]$.

Some EE-causing mutations are located at the N-lobe/helix B interface. One particular helix B mutation, M518V (M546V in isoform 1), leads to cellular degeneration, but it is unclear how this phenotype relates to CaM binding [106]. There are contrasting reports regarding the effect of the $\mathrm{K} 526 \mathrm{~N}$ (K554N in isoform 1) mutation on CaM binding, voltage-dependence, and membrane surface expression (Table 4; Figure 3). There is general agreement on an impact on $\mathrm{PIP}_{2}$ sensitivity and a tendency to increase current density $[105,106,113]$. Similar to other mutations at or close to the CaM binding surface, channels carrying this mutation are less efficient at controlling neuronal excitability [106].

Mutations at the helix A/C-lobe interface include L339R, W344R, L351F, L351V, and R353G (Table 4; Figure 3). All these mutations affect CaM binding, surface expression, and current density, with a reasonable degree of correspondence between these parameters [108-110,123]. Mutations at the R333 site, located at the periphery of the binding surface, differentially affect the interaction with CaM. Whereas the R333W mutant interferes with CaM binding, the R333Q mutation does not. However, both mutations affect channel trafficking $[105,106]$ (Table 4; Figure 3).

Interestingly, there are pathological mutations located in a site denominated TW helix [124], which is downstream of the IQ motif (Table 4). Although those mutants (L356V, T359R, and Y362C) do not participate in the interacting surface with $\mathrm{CaM}$, there is a clear impact on CaM binding that does not translate in changes in current density. Remarkably, the integrity of the TW site appears to be essential for CaM binding and function when the interacting surface at either helix A or helix B is perturbed [124]. CaM binding also affects the assembly of the C-terminal domain, and, in turn, helix D tetramerization influences CaM binding [116]. The pathological mutation L609R (L637R in isoform 1) in helix D disrupts tetrameric coiled-coil formation, upsets CaM-mediated potentiation, and makes the channels more resistant to $\mathrm{PIP}_{2}$ depletion $[97,115]$. 


\section{TrpV4 Channels}

Transient receptor potential vanilloid subtype $4(\operatorname{TrpV} 4)$ channels are cation-nonselective $\mathrm{Ca}^{2+}$-permeable with a 6-TM membrane topology similar to that of voltage-dependent $\mathrm{K}^{+}$channels, presenting a tetrameric arrangement as well. TrpV4 are polymodal receptors activated by a wide variety of chemical and physical stimuli that include membrane stretch, mild heat, endogenous metabolites and synthetic chemicals. CaM binds to a distal site located in the C-terminal region [125]. There is a site upstream of the CaMBD which has been proposed to maintain the channel in a non-conducting state, whereas activated CaM sterically interferes with this presumed auto-inhibitory domain. In this way, $\mathrm{Ca}^{2+}{ }_{-} \mathrm{CaM}$ could potentiate channel function in response to different stimuli.

Gain-of-function mutations in the auto-inhibitory site (E797K and P799L) turn the activity of TrpV4 channels mostly independent of $\mathrm{Ca}^{2+}-\mathrm{CaM}$ regulation [126] and cause skeletal dysplasia (SD; Table 5), characterized by abnormalities of cartilage and bone growth, resulting in abnormal shape and size of the skeleton and disproportion of the long bones, spine, and head.

Table 5. Mutations in TrpV4 channels influencing CaM binding. SD: skeletal dysplasia.

\begin{tabular}{ccccc}
\hline TrpV4 Mutation & Location & Interacting Site & Disease & Reference \\
\hline E797K & Pre-CaMBD & unknown & SD & {$[126]$} \\
P799L & Pre-CaMBD & unknown & SD & {$[126]$} \\
\hline
\end{tabular}

\section{SK2 Channels}

A recent report points to apamin sensitive $\mathrm{Ca}^{2+}{ }_{-} \mathrm{CaM}$-activated $\mathrm{K}^{+}$channels (SK) as a possible co-factor for the action of pathological CaM variants [127]. The CaM apo-C-lobe binds to a motif conserved among the SK channel family (LRxxWL) that is structurally equivalent to the IQ motif [10]. The C-lobe remains $\mathrm{Ca}^{2+}$ free in some SK variants, whereas the $\mathrm{N}$-lobe senses $\mathrm{Ca}^{2+}$ and gates the pore. As in voltage-dependent channels, the S4-S5 linker plays a critical role in gating, but, instead of a voltage sensor, is the N-lobe with the EF-hands opened due to $\mathrm{Ca}^{2+}$ occupancy which transmit the mechanical force to the S4-S5 linker of an adjacent subunit to gate the pore [17]. CALM mutations (N54I, F90L, N98S, D96V, and D130G) all reduce SK2 current density. Because the C-lobe remains indifferent to $\mathrm{Ca}^{2+}$ when bound to SK2 channels, it is remarkable that the $\mathrm{Ca}^{2+}$ sensitivity of SK channels increases significantly when engaged to the C-lobe D96V mutant. Of note, at a 1:3 ratio, closer to that imposed by genetic balance of one mutated allele and five wild-type, no major effect was observed for the D96V mutant, suggesting that this mutant lacks a dominant-negative effect on SK channel function [127].

In summary, mutations in CALM genes affect a plethora of targets, and it is expected that each contribute to some degree to the observed phenotype. In general, disruption of CaM interaction with its partners have multiple and variable consequences. Overall, as pointed out by Chung and collaborators, the multiple effects caused by direct or indirect disruption of the CaM binding interface have a synergistic influence, and, in conjunction exert more severe impacts on excitability and health [106].

Author Contributions: Writing-original draft preparation, J.U., A.A., and A.V. Writing-review and editing A.M-M., O.C., E.N, and C.M.

Funding: The Department of Industry, Tourism and Trade of the Government of the Autonomous Community of the Basque Country (Elkartek 2017 bG17 kk-2017/000843M50.17.EK.C6) and the Spanish Ministry of Economy, Industry and Competitiveness (BFU2015-66910 and RTI2018-097839) provided financial support for this work. E.N. is supported by a predoctoral grant of the Basque Government.

Conflicts of Interest: The authors declare no conflict of interest. 


\section{Abbreviations}

\begin{tabular}{|c|c|}
\hline BFNS & Benign familial neonatal seizures \\
\hline BrS & Brugada syndrome \\
\hline $\mathrm{CaM}$ & Calmodulin \\
\hline CaMBD & CaM-binding domains \\
\hline $\mathrm{Ca}_{\mathrm{V}}$ & Voltage-gated $\mathrm{Ca}^{2+}$-channels \\
\hline CDI & $\mathrm{Ca}^{2+}$-dependent inactivation \\
\hline CDR & $\mathrm{Ca}^{2+}$-dependent regulator \\
\hline CPVT & Catecholaminergic polymorphic ventricular tachycardia \\
\hline $\mathrm{D}_{\mathrm{I}}-\mathrm{D}_{\mathrm{IV}}$ & Homologous repeat domains \\
\hline ECC & Excitation-contraction coupling \\
\hline EE & Epileptic encephalopathy \\
\hline GF & Gingival fibromatosis \\
\hline hA & Helix A \\
\hline hB & Helix B \\
\hline hC & Helix C \\
\hline $\mathrm{hD}$ & Helix D \\
\hline hiPSC-CM & Human induced pluripotent stem cell-derived cardiomyocytes \\
\hline hTW & TW helix \\
\hline IGE & Idiopathic generalized epilepsy \\
\hline $\mathrm{I}_{\mathrm{Ks}}$ & Slow delayed rectifier potassium current \\
\hline IVF & Idiopathic ventricular fibrillation \\
\hline $\mathrm{K}_{\mathrm{V}} 7$ & Voltage-gated $\mathrm{K}^{+}$channels 7 \\
\hline LQTS & Long QT syndrome \\
\hline $\mathrm{Na}_{\mathrm{V}}$ & Voltage-gated $\mathrm{Na}^{+}$-channels \\
\hline NCX & $\mathrm{Na}^{+}-\mathrm{Ca}^{2+}$ exchanger \\
\hline NSCaTE & $\mathrm{N}$-terminal spatial $\mathrm{Ca}^{2+}$ transforming element \\
\hline OS & Ohtahara syndrome \\
\hline $\mathrm{PIP}_{2}$ & Phosphatidylinositol 4,5-bisphosphate \\
\hline RyR & Ryanodine receptor ion channels \\
\hline S1-S6 & Six transmembrane segments \\
\hline SCD & Sudden cardiac death \\
\hline SD & Skeletal dysplasia \\
\hline SK & Small conductance calcium activated potassium channel \\
\hline SQTS & Short QT syndromes \\
\hline SR & Sarcoplasmic reticulum \\
\hline TrpV4 & Transient receptor potential vanilloid subtype 4 \\
\hline
\end{tabular}

\section{References}

1. Hoeflich, K.P.; Ikura, M. Calmodulin in action: Diversity in target recognition and activation mechanisms. Cell 2002, 108, 739-742. [CrossRef]

2. Carafoli, E.; Krebs, J. Why Calcium? How Calcium Became the Best Communicator. J. Biol. Chem. 2016, 291, 20849-20857. [CrossRef] [PubMed]

3. Cheung, W.Y. Cyclic 3',5'-nucleotide phosphodiesterase. Demonstration of an activator. Biochem. Biophys. Res. Commun. 1970, 38, 533-538. [CrossRef]

4. Kakiuchi, S.; Yamazaki, R. Calcium dependent phosphodiesterase activity and its activating factor (PAF) from brain studies on cyclic 3',5'-nucleotide phosphodiesterase (3). Biochem. Biophys. Res. Commun. 1970, 41, 1104-1110. [CrossRef]

5. Klee, C.B.; Crouch, T.H.; Richman, P.G. Calmodulin. Annu. Rev. Biochem. 1980, 49, 489-515. [CrossRef] [PubMed]

6. Tidow, H.; Nissen, P. Structural diversity of calmodulin binding to its target sites. Febs J. 2013, 280, 5551-5565. [CrossRef] [PubMed] 
7. Preston, R.R.; Kink, J.A.; Hinrichsen, R.D.; Saimi, Y.; Kung, C. Calmodulin mutants and Ca ${ }^{2+}$-dependent channels in Paramecium. Annu. Rev. Physiol. 1991, 53, 309-319. [CrossRef]

8. Kink, J.A.; Maley, M.E.; Preston, R.R.; Ling, K.Y.; Wallen-Friedman, M.A.; Saimi, Y.; Kung, C. Mutations in paramecium calmodulin indicate functional differences between the C-terminal and $\mathrm{N}$-terminal lobes in vivo. Cell 1990, 62, 165-174. [CrossRef]

9. Linse, S.; Helmersson, A.; Forsen, S. Calcium binding to calmodulin and its globular domains. J. Biol. Chem. 1991, 266, 8050-8054.

10. Villarroel, A.; Taglialatela, M.; Bernardo-Seisdedos, G.; Alaimo, A.; Agirre, J.; Alberdi, A.; Gomis-Perez, C.; Soldovieri, M.V.; Ambrosino, P.; Malo, C.; et al. The ever changing moods of calmodulin: How structural plasticity entails transductional adaptability. J. Mol. Biol. 2014, 426, 2717-2735. [CrossRef]

11. Jurado, L.A.; Chockalingam, P.S.; Jarrett, H.W. Apocalmodulin. Physiol. Rev. 1999, 79, 661-682. [CrossRef] [PubMed]

12. Ikura, M.; Ames, J.B. Genetic polymorphism and protein conformational plasticity in the calmodulin superfamily: Two ways to promote multifunctionality. Proc. Natl. Acad. Sci. USA 2006, 103, 1159-1164. [CrossRef] [PubMed]

13. Schumacher, M.A.; Rivard, A.F.; Bachinger, H.P.; Adelman, J.P. Structure of the gating domain of a $\mathrm{Ca}^{2+}$-activated $\mathrm{K}^{+}$channel complexed with $\mathrm{Ca}^{2+} /$ calmodulin. Nature 2001, 410, 1120-1124. [CrossRef] [PubMed]

14. Alaimo, A.; Alberdi, A.; Gomis-Perez, C.; Fernandez-Orth, J.; Bernardo-Seisdedos, G.; Malo, C.; Millet, O.; Areso, P.; Villarroel, A. Pivoting between Calmodulin Lobes Triggered by Calcium in the Kv7.2/Calmodulin Complex. PLoS ONE 2014, 9, e86711. [CrossRef] [PubMed]

15. Sachyani, D.; Dvir, M.; Strulovich, R.; Tria, G.; Tobelaim, W.; Peretz, A.; Pongs, O.; Svergun, D.; Attali, B.; Hirsch, J.A. Structural Basis of a Kv7.1 Potassium Channel Gating Module: Studies of the Intracellular C-Terminal Domain in Complex with Calmodulin. Structure 2014, 22, 1582-1594. [CrossRef]

16. Tobelaim, W.S.; Dvir, M.; Lebel, G.; Cui, M.; Buki, T.; Peretz, A.; Marom, M.; Haitin, Y.; Logothetis, D.E.; Hirsch, J.A.; et al. $\mathrm{Ca}^{2+}$-Calmodulin and $\mathrm{PIP}_{2}$ interactions at the proximal C-terminus of Kv7 channels. Channels 2017, 11, 686-695. [CrossRef]

17. Lee, C.H.; MacKinnon, R. Activation mechanism of a human SK-calmodulin channel complex elucidated by cryo-EM structures. Science 2018, 360, 508-513. [CrossRef]

18. Kung, C.; Preston, R.R.; Maley, M.E.; Ling, K.Y.; Kanabrocki, J.A.; Seavey, B.R.; Saimi, Y. In vivo Paramecium mutants show that calmodulin orchestrates membrane responses to stimuli. Cell Calcium 1992, 13, 413-425. [CrossRef]

19. Nyegaard, M.; Overgaard, M.T.; Sondergaard, M.T.; Vranas, M.; Behr, E.R.; Hildebrandt, L.L.; Lund, J.; Hedley, P.L.; Camm, A.J.; Wettrell, G.; et al. Mutations in calmodulin cause ventricular tachycardia and sudden cardiac death. Am. J. Hum. Genet. 2012, 91, 703-712. [CrossRef]

20. Marshall, C.B.; Nishikawa, T.; Osawa, M.; Stathopulos, P.B.; Ikura, M. Calmodulin and STIM proteins: Two major calcium sensors in the cytoplasm and endoplasmic reticulum. Biochem. Biophys. Res. Commun. 2015, 460, 5-21. [CrossRef]

21. Marsman, R.F.; Tan, H.L.; Bezzina, C.R. Genetics of sudden cardiac death caused by ventricular arrhythmias. Nat. Rev. Cardiol. 2014, 11, 96-111. [CrossRef] [PubMed]

22. Sanguinetti, M.C.; Tristani-Firouzi, M. hERG potassium channels and cardiac arrhythmia. Nature 2006, 440, 463-469. [CrossRef] [PubMed]

23. Mohler, P.J.; Schott, J.J.; Gramolini, A.O.; Dilly, K.W.; Guatimosim, S.; DuBell, W.H.; Song, L.S.; Haurogne, K.; Kyndt, F.; Ali, M.E.; et al. Ankyrin-B mutation causes type 4 long-QT cardiac arrhythmia and sudden cardiac death. Nature 2003, 421, 634-639. [CrossRef] [PubMed]

24. Vatta, M.; Faulkner, G. Cytoskeletal basis of ion channel function in cardiac muscle. Future. Cardiol. 2006, 2, 467-476. [CrossRef] [PubMed]

25. Chen, L.; Marquardt, M.L.; Tester, D.J.; Sampson, K.J.; Ackerman, M.J.; Kass, R.S. Mutation of an A-kinase-anchoring protein causes long-QT syndrome. Proc. Natl. Acad. Sci. USA 2007, 104, 20990-20995. [CrossRef] [PubMed]

26. Crotti, L.; Johnson, C.N.; Graf, E.; De Ferrari, G.M.; Cuneo, B.F.; Ovadia, M.; Papagiannis, J.; Feldkamp, M.D.; Rathi, S.G.; et al. Calmodulin mutations associated with recurrent cardiac arrest in infants. Circulation 2013, 127, 1009-1017. [CrossRef] [PubMed] 
27. Zuhlke, R.D.; Pitt, G.S.; Deisseroth, K.; Tsien, R.W.; Reuter, H. Calmodulin supports both inactivation and facilitation of L-type calcium channels. Nature 1999, 399, 159-162. [CrossRef] [PubMed]

28. Colinas, O.; Gallego, M.; Setien, R.; Lopez-Lopez, J.R.; Perez-Garcia, M.T.; Casis, O. Differential modulation of Kv4.2 and Kv4.3 channels by calmodulin-dependent protein kinase II in rat cardiac myocytes. Am. J. Physiol. Heart Circ. Physiol. 2006, 291, H1978-H1987. [CrossRef] [PubMed]

29. Gallego, M.; Fernandez, D.; Ahyayauch, H.; Casis, E.; Casis, O. Reduced calmodulin expression accelerates transient outward potassium current inactivation in diabetic rat heart. Cell Physiol. Biochem. 2008, 22, 625-634. [CrossRef] [PubMed]

30. Howard, T.; Greer-Short, A.; Satroplus, T.; Patel, N.; Nassal, D.; Mohler, P.J.; Hund, T.J. CaMKII-dependent late $\mathrm{Na}^{+}$current increases electrical dispersion and arrhythmia in ischemia-reperfusion. Am. J. Physiol Heart Circ. Physiol. 2018, 315, H794-H801. [CrossRef]

31. Crotti, L.; Kotta, M.C. The role of genetics in primary ventricular fibrillation, inherited channelopathies and cardiomyopathies. Int. J. Cardiol. 2017, 237, 45-48. [CrossRef] [PubMed]

32. Kotta, M.C.; Sala, L.; Ghidoni, A.; Badone, B.; Ronchi, C.; Parati, G.; Zaza, A.; Crotti, L. Calmodulinopathy: A Novel, Life-Threatening Clinical Entity Affecting the Young. Front. Cardiovasc. Med. 2018, 5, 175. [CrossRef] [PubMed]

33. Badone, B.; Ronchi, C.; Kotta, M.C.; Sala, L.; Ghidoni, A.; Crotti, L.; Zaza, A. Calmodulinopathy: Functional Effects of CALM Mutations and Their Relationship With Clinical Phenotypes. Front. Cardiovasc. Med. 2018, 5, 176. [CrossRef] [PubMed]

34. George, A.L., Jr. Calmodulinopathy: A genetic trilogy. Heart Rhythm 2015, 12, 423-424. [CrossRef] [PubMed]

35. Jensen, H.H.; Brohus, M.; Nyegaard, M.; Overgaard, M.T. Human Calmodulin Mutations. Front. Mol. Neurosci. 2018, 11, 396. [CrossRef] [PubMed]

36. Wang, K.; Holt, C.; Lu, J.; Brohus, M.; Larsen, K.T.; Overgaard, M.T.; Wimmer, R.; Van, P.F. Arrhythmia mutations in calmodulin cause conformational changes that affect interactions with the cardiac voltage-gated calcium channel. Proc. Natl. Acad. Sci. USA 2018, 115, E10556-E10565. [CrossRef]

37. Veeraraghavan, R.; Gyorke, S.; Radwanski, P.B. Neuronal sodium channels: Emerging components of the nano-machinery of cardiac calcium cycling. J. Physiol. 2017, 595, 3823-3834. [CrossRef] [PubMed]

38. Niwa, N.; Nerbonne, J.M. Molecular determinants of cardiac transient outward potassium current (I(to)) expression and regulation. J. Mol. Cell Cardiol. 2010, 48, 12-25. [CrossRef] [PubMed]

39. Choi, S.H.; Lee, B.H.; Kim, H.J.; Jung, S.W.; Kim, H.S.; Shin, H.C.; Lee, J.H.; Kim, H.C.; Rhim, H.; Hwang, S.H. Ginseng gintonin activates the human cardiac delayed rectifier $\mathrm{K}^{+}$channel: Involvement of $\mathrm{Ca}^{2+} /$ calmodulin binding sites. Mol. Cells 2014, 37, 656-663. [CrossRef] [PubMed]

40. Hegyi, B.; Chen-Izu, Y.; Jian, Z.; Shimkunas, R.; Izu, L.T.; Banyasz, T. KN-93 inhibits IKr in mammalian cardiomyocytes. J. Mol. Cell Cardiol. 2015, 89, 173-176. [CrossRef]

41. Qu, Y.J.; Bondarenko, V.E.; Xie, C.; Wang, S.; Awayda, M.S.; Strauss, H.C.; Morales, M. W-7 modulates Kv4.3: Pore block and $\mathrm{Ca}^{2+}$-calmodulin inhibition. Am. J. Physiol. Heart Circ. Physiol. 2007, 292, H2364-H2377. [CrossRef] [PubMed]

42. Priori, S.G.; Napolitano, C.; Memmi, M.; Colombi, B.; Drago, F.; Gasparini, M.; DeSimone, L.; Coltorti, F.; Bloise, R.; Keegan, R.; et al. Clinical and molecular characterization of patients with catecholaminergic polymorphic ventricular tachycardia. Circulation 2002, 106, 69-74. [CrossRef]

43. Yano, M.; Yamamoto, T.; Ikeda, Y.; Matsuzaki, M. Mechanisms of Disease: Ryanodine receptor defects in heart failure and fatal arrhythmia. Nat. Clin. Pract. Cardiovasc. Med. 2006, 3, 43-52. [CrossRef] [PubMed]

44. Chopra, N.; Knollmann, B.C. Genetics of sudden cardiac death syndromes. Curr. Opin. Cardiol. 2011, 26, 196-203. [CrossRef] [PubMed]

45. Laver, D.R. Regulation of the RyR channel gating by $\mathrm{Ca}^{2+}$ and $\mathrm{Mg}^{2+}$. Biophys. Rev. 2018, 10, $1087-1095$. [CrossRef] [PubMed]

46. Xu, X.; Yano, M.; Uchinoumi, H.; Hino, A.; Suetomi, T.; Ono, M.; Tateishi, H.; Oda, T.; Okuda, S.; Doi, M.; et al. Defective calmodulin binding to the cardiac ryanodine receptor plays a key role in CPVT-associated channel dysfunction. Biochem. Biophys. Res. Commun. 2010, 394, 660-666. [CrossRef] [PubMed]

47. Yamaguchi, N.; Takahashi, N.; Xu, L.; Smithies, O.; Meissner, G. Early cardiac hypertrophy in mice with impaired calmodulin regulation of cardiac muscle Ca release channel. J. Clin. Investig. 2007, 117, 1344-1353. [CrossRef] [PubMed] 
48. Yamaguchi, N.; Chakraborty, A.; Huang, T.Q.; Xu, L.; Gomez, A.C.; Pasek, D.A.; Meissner, G. Cardiac hypertrophy associated with impaired regulation of cardiac ryanodine receptor by calmodulin and S100A1. Am. J. Physiol. Heart Circ. Physiol. 2013, 305, H86-H94. [CrossRef] [PubMed]

49. Eisner, D.A.; Caldwell, J.L.; Kistamas, K.; Trafford, A.W. Calcium and Excitation-Contraction Coupling in the Heart. Circ. Res. 2017, 121, 181-195. [CrossRef] [PubMed]

50. Dixon, R.E.; Moreno, C.M.; Yuan, C.; Opitz-Araya, X.; Binder, M.D.; Navedo, M.F.; Santana, L.F. Graded $\mathrm{Ca}^{2+} /$ calmodulin-dependent coupling of voltage-gated Cav1 1.2 channels. Elife 2015, 4, e05608. [CrossRef] [PubMed]

51. Limpitikul, W.B.; Dick, I.E.; Joshi-Mukherjee, R.; Overgaard, M.T.; George, A.L., Jr.; Yue, D.T. Calmodulin Mutations Associated with Long QT Syndrome Prevent Inactivation of Cardiac L-type Ca Currents and Promote Proarrhythmic Behavior in Ventricular Myocytes. J. Mol. Cell Cardiol. 2014, 74, 115-124. [CrossRef] [PubMed]

52. Waddell-Smith, K.E.; Skinner, J.R. Update on the Diagnosis and Management of Familial Long QT Syndrome. Heart Lung Circ. 2016, 25, 769-776. [CrossRef] [PubMed]

53. Rocchetti, M.; Sala, L.; Dreizehnter, L.; Crotti, L.; Sinnecker, D.; Mura, M.; Pane, L.S.; Altomare, C.; Torre, E.; Mostacciuolo, G.; et al. Elucidating arrhythmogenic mechanisms of long-QT syndrome CALM1-F142L mutation in patient-specific induced pluripotent stem cell-derived cardiomyocytes. Cardiovasc. Res. 2017, 113, 531-541. [CrossRef] [PubMed]

54. Makita, N.; Yagihara, N.; Crotti, L.; Johnson, C.N.; Beckmann, B.M.; Roh, M.S.; Shigemizu, D.; Lichtner, P.; Ishikawa, T.; Aiba, T.; et al. Novel calmodulin mutations associated with congenital arrhythmia susceptibility. Circ. Cardiovasc. Genet. 2014, 7, 466-474. [CrossRef] [PubMed]

55. Erickson, M.G.; Liang, H.Y.; Mori, M.X.; Yue, D.T. FRET two-hybrid mapping reveals function and location of L-type $\mathrm{Ca}^{2+}$ channel CaM preassociation. Neuron 2003, 39, 97-107. [CrossRef]

56. Rhoads, A.R.; Friedberg, F. Sequence motifs for calmodulin recognition. Faseb J. 1997, 11, 331-340. [CrossRef]

57. Li, Y.; Maleki, M.; Carruthers, N.J.; Stemmer, P.M.; Ngom, A.; Rueda, L. The predictive performance of short-linear motif features in the prediction of calmodulin-binding proteins. BMC Bioinform. 2018, 19, 410. [CrossRef]

58. Mruk, K.; Farley, B.M.; Ritacco, A.W.; Kobertz, W.R. Calmodulation meta-analysis: Predicting calmodulin binding via canonical motif clustering. J. Gen. Physiol. 2014, 144, 105-114. [CrossRef]

59. Yap, K.L.; Kim, J.; Truong, K.; Sherman, M.; Yuan, T.; Ikura, M. Calmodulin target database. J. Struct. Funct. Genom. 2000, 1, 8-14. [CrossRef]

60. Hovey, L.; Fowler, C.A.; Mahling, R.; Lin, Z.; Miller, M.S.; Marx, D.C.; Yoder, J.B.; Kim, E.H.; Tefft, K.M.; Waite, B.C.; et al. Calcium triggers reversal of calmodulin on nested anti-parallel sites in the IQ motif of the neuronal voltage-dependent sodium channel Nav1.2. Biophys. Chem. 2017, 224, 1-19.

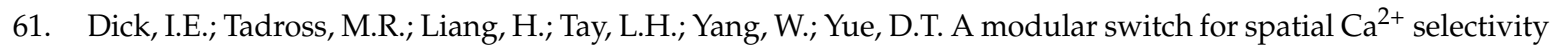
in the calmodulin regulation of $\mathrm{Ca}_{\mathrm{V}}$ channels. Nature 2008, 451, 830-834. [CrossRef] [PubMed]

62. Simms, B.A.; Souza, I.A.; Zamponi, G.W. Effect of the Brugada syndrome mutation A39V on calmodulin regulation of Cav1.2 channels. Mol. Brain 2014, 7, 34. [CrossRef] [PubMed]

63. Brugada, P.; Brugada, J. Right bundle branch block, persistent ST segment elevation and sudden cardiac death: A distinct clinical and electrocardiographic syndrome. A multicenter report. J. Am. Coll. Cardiol. 1992, 20, 1391-1396. [CrossRef]

64. Antzelevitch, C.; Pollevick, G.D.; Cordeiro, J.M.; Casis, O.; Sanguinetti, M.C.; Aizawa, Y.; Guerchicoff, A.; Pfeiffer, R.; Oliva, A.; Wollnik, B.; et al. Loss-of-function mutations in the cardiac calcium channel underlie a new clinical entity characterized by ST-segment elevation, short QT intervals, and sudden cardiac death. Circulation 2007, 115, 442-449. [CrossRef] [PubMed]

65. Gabelli, S.B.; Yoder, J.B.; Tomaselli, G.F.; Amzel, L.M. Calmodulin and $\mathrm{Ca}^{2+}$ control of voltage gated $\mathrm{Na}^{+}$ channels. Channels 2016, 10, 45-54. [CrossRef] [PubMed]

66. Yan, H.; Wang, C.; Marx, S.O.; Pitt, G.S. Calmodulin limits pathogenic $\mathrm{Na}^{+}$channel persistent current. J. Gen. Physiol. 2017, 149, 277-293. [CrossRef] [PubMed]

67. Ben-Johny, M.; Yang, P.S.; Niu, J.; Yang, W.; Joshi-Mukherjee, R.; Yue, D.T. Conservation of Ca ${ }^{2+} /$ calmodulin $^{2}$ regulation across $\mathrm{Na}^{+}$and $\mathrm{Ca}^{2+}$ channels. Cell 2014, 157, 1657-1670. [CrossRef] [PubMed]

68. Kapplinger, J.D.; Giudicessi, J.R.; Ye, D.; Tester, D.J.; Callis, T.E.; Valdivia, C.R.; Makielski, J.C.; Wilde, A.A.; Ackerman, M.J. Enhanced Classification of Brugada Syndrome-Associated and Long-QT 
Syndrome-Associated Genetic Variants in the SCN5A-Encoded Nav1.5 Cardiac Sodium Channel. Circ. Cardiovasc. Genet. 2015, 8, 582-595. [CrossRef]

69. Winkel, B.G.; Larsen, M.K.; Berge, K.E.; Leren, T.P.; Nissen, P.H.; Olesen, M.S.; Hollegaard, M.V.; Jespersen, T.; Yuan, L.; Nielsen, N.; et al. The prevalence of mutations in KCNQ1, KCNH2, and SCN5A in an unselected national cohort of young sudden unexplained death cases. J. Cardiovasc. Electrophysiol. 2012, 23, 1092-1098. [CrossRef]

70. Abdelsayed, M.; Baruteau, A.E.; Gibbs, K.; Sanatani, S.; Krahn, A.D.; Probst, V.; Ruben, P.C. Differential calcium sensitivity in Nav1.5 mixed syndrome mutants. J. Physiol. 2017, 595, 6165-6186. [CrossRef]

71. Chagot, B.; Chazin, W.J. Solution NMR structure of Apo-calmodulin in complex with the IQ motif of human cardiac sodium channel NaV1.5. J. Mol. Biol. 2011, 406, 106-119. [CrossRef] [PubMed]

72. Johnson, C.N.; Potet, F.; Thompson, M.K.; Kroncke, B.M.; Glazer, A.M.; Voehler, M.W.; Knollmann, B.C.; George, A.L., Jr.; Chazin, W.J. A Mechanism of Calmodulin Modulation of the Human Cardiac Sodium Channel. Structure 2018, 26, 683-694. [CrossRef]

73. Hedley, P.L.; Jorgensen, P.; Schlamowitz, S.; Wangari, R.; Moolman-Smook, J.; Brink, P.A.; Kanters, J.K.; Corfield, V.A.; Christiansen, M. The genetic basis of long QT and short QT syndromes: A mutation update. Hum. Mutat. 2009, 30, 1486-1511. [CrossRef] [PubMed]

74. Kapplinger, J.D.; Tester, D.J.; Alders, M.; Benito, B.; Berthet, M.; Brugada, J.; Brugada, P.; Fressart, V.; Guerchicoff, A.; Harris-Kerr, C.; et al. An international compendium of mutations in the SCN5A-encoded cardiac sodium channel in patients referred for Brugada syndrome genetic testing. Heart Rhythm 2010, 7 , 33-46. [CrossRef] [PubMed]

75. Deschenes, I.; Baroudi, G.; Berthet, M.; Barde, I.; Chalvidan, T.; Denjoy, I.; Guicheney, P.; Chahine, M. Electrophysiological characterization of SCN5A mutations causing long QT (E1784K) and Brugada (R1512W and R1432G) syndromes. Cardiovasc. Res. 2000, 46, 55-65. [CrossRef]

76. Yokoi, H.; Makita, N.; Sasaki, K.; Takagi, Y.; Okumura, Y.; Nishino, T.; Makiyama, T.; Kitabatake, A.; Horie, M.; Watanabe, I.; et al. Double SCN5A mutation underlying asymptomatic Brugada syndrome. Heart Rhythm. 2005, 2, 285-292. [CrossRef] [PubMed]

77. Gardill, B.R.; Rivera-Acevedo, R.E.; Tung, C.C.; Okon, M.; McIntosh, L.P.; Van Petegem, F. The voltage-gated sodium channel EF-hands form an interaction with the III-IV linker that is disturbed by disease-causing mutations. Sci. Rep. 2018, 8, 4483. [CrossRef] [PubMed]

78. Olesen, M.S.; Yuan, L.; Liang, B.; Holst, A.G.; Nielsen, N.; Nielsen, J.B.; Hedley, P.L.; Christiansen, M.; Olesen, S.P.; Haunso, S.; et al. High prevalence of long QT syndrome-associated SCN5A variants in patients with early-onset lone atrial fibrillation. Circ. Cardiovasc. Genet. 2012, 5, 450-459. [CrossRef] [PubMed]

79. Pan, X.; Li, Z.; Zhou, Q.; Shen, H.; Wu, X.; Huang, X.; Chen, J.; Zhang, J.; Zhu, X.; Lei, J.; et al. Structure of the human voltage-gated sodium channel Nav1.4 in complex with beta1. Science 2018, 362, eaau2486. [CrossRef] [PubMed]

80. Shen, H.; Zhou, Q.; Pan, X.; Li, Z.; Wu, J.; Yan, N. Structure of a eukaryotic voltage-gated sodium channel at near-atomic resolution. Science 2017, 355, eaal4326. [CrossRef]

81. Kim, J.; Ghosh, S.; Liu, H.; Tateyama, M.; Kass, R.S.; Pitt, G.S. Calmodulin mediates Ca ${ }^{2+}$ sensitivity of sodium channels. J. Biol. Chem. 2004, 279, 45004-45012. [CrossRef] [PubMed]

82. Gabelli, S.B.; Boto, A.; Kuhns, V.H.; Bianchet, M.A.; Farinelli, F.; Aripirala, S.; Yoder, J.; Jakoncic, J.; Tomaselli, G.F.; Amzel, L.M. Regulation of the $\mathrm{Na}_{\mathrm{V}} 1.5$ cytoplasmic domain by calmodulin. Nat. Commun. 2014, 5, 5126. [CrossRef] [PubMed]

83. Clatot, J.; Hoshi, M.; Wan, X.; Liu, H.; Jain, A.; Shinlapawittayatorn, K.; Marionneau, C.; Ficker, E.; Ha, T.; Deschenes, I. Voltage-gated sodium channels assemble and gate as dimers. Nat. Commun. 2017, 8, 2077. [CrossRef]

84. Yus-Nájera, E.; Santana-Castro, I.; Villarroel, A. The identification and characterization of a noncontinuous calmodulin-binding site in noninactivating voltage-dependent KCNQ potassium channels. J. Biol. Chem. 2002, 277, 28545-28553. [CrossRef]

85. Ghosh, S.; Nunziato, D.A.; Pitt, G.S. KCNQ1 assembly and function is blocked by long-QT syndrome mutations that disrupt interaction with calmodulin. Circ. Res. 2006, 98, 1048-1054. [CrossRef] [PubMed]

86. Shamgar, L.; Ma, L.J.; Schmitt, N.; Haitin, Y.; Peretz, A.; Wiener, R.; Hirsch, J.; Pongs, O.; Attali, B. Calmodulin is essential for cardiac $\mathrm{I}_{\mathrm{Ks}}$ channel gating and assembly-Impaired function in long-QT mutations. Circ. Res. 2006, 98, 1055-1063. [CrossRef] [PubMed] 
87. Sun, J.; MacKinnon, R. Cryo-EM Structure of a KCNQ1/CaM Complex Reveals Insights into Congenital Long QT Syndrome. Cell 2017, 169, 1042-1050. [CrossRef]

88. Schmitt, N.; Calloe, K.; Nielsen, N.H.; Buschmann, M.; Speckmann, E.J.; Schulze-Bahr, E.; Schwarz, M. The novel C-terminal KCNQ1 mutation M520R alters protein trafficking. Biochem. Biophys. Res. Commun. 2007, 358, 304-310. [CrossRef]

89. Tobelaim, W.S.; Dvir, M.; Lebel, G.; Cui, M.; Buki, T.; Peretz, A.; Marom, M.; Haitin, Y.; Logothetis, D.E.; Hirsch, J.A.; et al. Competition of calcified calmodulin N lobe and PIP 2 to an LQT mutation site in Kv7.1 channel. Proc. Natl. Acad. Sci. USA 2017, 114, E869-E878. [CrossRef]

90. Chang, A.; Abderemane-Ali, F.; Hura, G.L.; Rossen, N.D.; Gate, R.E.; Minor, D.L., Jr. A Calmodulin C-Lobe $\mathrm{Ca}^{2+}$-Dependent Switch Governs Kv7 Channel Function. Neuron 2018, 97, 836-852. [CrossRef]

91. Bernardo-Seisdedos, G.; Nunez, E.; Gomis, C.; Malo, C.; Villarroel, A.; Millet, O. Structural basis and energy landscape for the $\mathrm{Ca}^{2+}$ gating and calmodulation of the Kv7.2 $\mathrm{K}^{+}$channel. Proc. Natl. Acad. Sci. USA 2018, 115, 2395-2400. [CrossRef]

92. Tommiska, J.; Kansakoski, J.; Skibsbye, L.; Vaaralahti, K.; Liu, X.; Lodge, E.J.; Tang, C.; Yuan, L.; Fagerholm, R.; Kanters, J.K.; et al. Two missense mutations in KCNQ1 cause pituitary hormone deficiency and maternally inherited gingival fibromatosis. Nat. Commun. 2017, 8, 1289. [CrossRef]

93. Larsen, L.A.; Fosdal, I.; Andersen, P.S.; Kanters, J.K.; Vuust, J.; Wettrell, G.; Christiansen, M. Recessive Romano-Ward syndrome associated with compound heterozygosity for two mutations in the KVLQT1 gene. Eur. J. Hum. Genet. 1999, 7, 724-728. [CrossRef]

94. Antunez-Arguelles, E.; Rojo-Dominguez, A.; Arregui-Mena, A.L.; Jacobo-Albavera, L.; Marquez, M.F.; Iturralde-Torres, P.; Villarreal-Molina, M.T. Compound heterozygous KCNQ1 mutations (A300T/P535T) in a child with sudden unexplained death: Insights into possible molecular mechanisms based on protein modeling. Gene 2017, 627, 40-48. [CrossRef] [PubMed]

95. Li, Y.; Zaydman, M.A.; Wu, D.; Shi, J.; Guan, M.; Virgin-Downey, B.; Cui, J. KCNE1 enhances phosphatidylinositol 4,5-bisphosphate ( $\left.\mathrm{PIP}_{2}\right)$ sensitivity of $\mathrm{I}_{\mathrm{Ks}}$ to modulate channel activity. Proc. Natl. Acad. Sci. USA 2011, 108, 9095-9100. [CrossRef]

96. Kang, S.; Xu, M.; Cooper, E.C.; Hoshi, N. Channel anchored protein kinase CK2 and protein phosphatase 1 reciprocally regulate KCNQ2-containing M-channels via phosphorylation of calmodulin. J. Biol. Chem. 2014, 289, 11536-11544. [CrossRef] [PubMed]

97. Gomis-Perez, C.; Soldovieri, M.V.; Malo, C.; Ambrosino, P.; Taglialatela, M.; Areso, P.; Villarroel, A. Differential Regulation of $\mathrm{PI}(4,5) \mathrm{P}_{2}$ Sensitivity of Kv7.2 and Kv7.3 Channels by Calmodulin. Front. Mol. Neurosci. 2017, 10, 117. [CrossRef]

98. Haug, K.; Hallmann, K.; Rebstock, J.; Dullinger, J.; Muth, S.; Haverkamp, F.; Pfeiffer, H.; Rau, B.; Elger, C.E.; Propping, P.; et al. The voltage-gated sodium channel gene SCN2A and idiopathic generalized epilepsy. Epilepsy Res. 2001, 47, 243-246. [CrossRef]

99. Wang, C.; Chung, B.C.; Yan, H.; Wang, H.G.; Lee, S.Y.; Pitt, G.S. Structural analyses of Ca ${ }^{2+} / \mathrm{CaM}$ interaction with $\mathrm{Na}_{V}$ channel C-termini reveal mechanisms of calcium-dependent regulation. Nat. Commun. 2014, 5, 4896. [CrossRef] [PubMed]

100. Biervert, C.; Schroeder, B.C.; Kubisch, C.; Berkovic, S.F.; Propping, P.; Jentsch, T.J.; Steinlein, O.K. A potassium channel mutation in neonatal human epilepsy. Science 1998, 279, 403-406. [CrossRef] [PubMed]

101. Singh, N.A.; Charlier, C.; Stauffer, D.; DuPont, B.R.; Leach, R.J.; Melis, R.; Ronen, G.M.; Bjerre, I.; Quattlebaum, T.; Murphy, J.V.; et al. A novel potassium channel gene, KCNQ2, is mutated in an inherited epilepsy of newborns. Nat. Genet. 1998, 18, 25-29. [CrossRef] [PubMed]

102. Charlier, C.; Singh, N.A.; Ryan, S.G.; Lewis, T.B.; Reus, B.E.; Leach, R.J.; Leppert, M. A pore mutation in a novel KQT-like potassium channel gene in an idiopathic epilepsy family. Nat. Genet. 1998, 18, 53-55. [CrossRef]

103. Kato, M.; Yamagata, T.; Kubota, M.; Arai, H.; Yamashita, S.; Nakagawa, T.; Fujii, T.; Sugai, K.; Imai, K.; Uster, T.; et al. Clinical spectrum of early onset epileptic encephalopathies caused by KCNQ2 mutation. Epilepsia 2013, 54, 1282-1287. [CrossRef] [PubMed]

104. Weckhuysen, S.; Mandelstam, S.; Suls, A.; Audenaert, D.; Deconinck, T.; Claes, L.R.; Deprez, L.; Smets, K.; Hristova, D.; Yordanova, I.; et al. KCNQ2 encephalopathy: Emerging phenotype of a neonatal epileptic encephalopathy. Ann. Neurol. 2012, 71, 15-25. [CrossRef] [PubMed] 
105. Alaimo, A.; Etxeberria, A.; Gomez-Posada, J.C.; Gomis-Perez, C.; Fernandez-Orth, J.; Malo, C.; Villarroel, A. Lack of correlation between surface expression and currents in epileptogenic AB-calmodulin binding domain Kv7.2 potassium channel mutants. Channels 2018, 12, 299-310. [CrossRef] [PubMed]

106. Kim, E.C.; Zhang, J.; Pang, W.; Wang, S.; Lee, K.Y.; Cavaretta, J.P.; Walters, J.; Procko, E.; Tsai, N.P.; Chung, H.J. Reduced axonal surface expression and phosphoinositide sensitivity in Kv7 channels disrupts their function to inhibit neuronal excitability in Kcnq2 epileptic encephalopathy. Neurobiol. Dis. 2018, 118, 76-93. [CrossRef]

107. Bellini, G.; Miceli, F.; Soldovieri, M.V.; Miraglia del, G.E.; Coppola, G.; Taglialatela, M. KCNQ2-Related Disorders. 2010. Available online: http:/ / www.ncbi.nlm.nih.gov/books/NBK32534/ (accessed on 1 December 2018).

108. Etxeberria, A.; Aivar, P.; Rodriguez-Alfaro, J.A.; Alaimo, A.; Villace, P.; Gomez-Posada, J.C.; Areso, P.; Villarroel, A. Calmodulin regulates the trafficking of KCNQ2 potassium channels. Faseb J. 2008, 22, 1135-1143. [CrossRef]

109. Ambrosino, P.; Alaimo, A.; Bartollino, S.; Manocchio, L.; De, M.M.; Mosca, I.; Gomis-Perez, C.; Alberdi, A.; Scambia, G.; Lesca, G.; et al. Epilepsy-causing mutations in Kv7.2 C-terminus affect binding and functional modulation by calmodulin. Biochim. Biophys. Acta 2015, 1852, 1856-1866. [CrossRef]

110. Alaimo, A.; Gomez-Posada, J.C.; Aivar, P.; Etxeberria, A.; Rodriguez-Alfaro, J.A.; Areso, P.; Villarroel, A. Calmodulin activation limits the rate of $\mathrm{KCNQ} 2 \mathrm{~K}^{+}$channel exit from the endoplasmic reticulum. J. Biol. Chem. 2009, 284, 20668-20675. [CrossRef]

111. Cavaretta, J.P.; Sherer, K.R.; Lee, K.Y.; Kim, E.H.; Issema, R.S.; Chung, H.J. Polarized axonal surface expression of neuronal KCNQ potassium channels is regulated by calmodulin interaction with KCNQ2 subunit. PLoS ONE 2014, 9, e103655. [CrossRef]

112. Volkers, L.; Rook, M.B.; Das, J.H.; Verbeek, N.E.; Groenewegen, W.A.; van Kempen, M.J.; Lindhout, D.; Koeleman, B.P. Functional analysis of novel KCNQ2 mutations found in patients with Benign Familial Neonatal Convulsions. Neurosci. Lett. 2009, 462, 24-29. [CrossRef] [PubMed]

113. Borgatti, R.; Zucca, C.; Cavallini, A.; Ferrario, M.; Panzeri, C.; Castaldo, P.; Soldovieri, M.V.; Baschirotto, C.; Bresolin, N.; Dalla Bernardina, B.; et al. A novel mutation in KCNQ2 associated with BFNC, drug resistant epilepsy, and mental retardation. Neurology 2004, 63, 57-65. [CrossRef] [PubMed]

114. Weckhuysen, S.; Ivanovic, V.; Hendrickx, R.; van Coster, R.; Hjalgrim, H.; Moller, R.S.; Gronborg, S.; Schoonjans, A.S.; Ceulemans, B.; Heavin, S.B.; et al. Extending the KCNQ2 encephalopathy spectrum: Clinical and neuroimaging findings in 17 patients. Neurology 2013, 81, 1697-1703. [CrossRef] [PubMed]

115. Alberdi, A.; Gomis-Perez, C.; Bernardo-Seisdedos, G.; Alaimo, A.; Malo, C.; Aldaregia, J.; Lopez-Robles, C.; Areso, P.; Butz, E.; Wahl-Schott, C.; et al. Uncoupling PIP 2 -calmodulin regulation of Kv7.2 channels by an assembly de-stabilizing epileptogenic mutation. J. Cell Sci. 2015, 128, 4014-4023. [CrossRef] [PubMed]

116. Alaimo, A.; Nunez, E.; Aivar, P.; Fernandez-Orth, J.; Gomis-Perez, C.; Bernardo-Seisdedos, G.; Malo, C.; Villarroel, A. Calmodulin confers calcium sensitivity to the stability of the distal intracellular assembly domain of Kv7.2 channels. Sci. Rep. 2017, 7, 13425. [CrossRef] [PubMed]

117. Chung, H.J.; Jan, Y.N.; Jan, L.Y. Polarized axonal surface expression of neuronal KCNQ channels is mediated by multiple signals in the KCNQ2 and KCNQ3 C-terminal domains. Proc. Natl. Acad. Sci. USA 2006, 103, 8870-8875. [CrossRef] [PubMed]

118. Chung, H.J. Role of calmodulin in neuronal Kv7/KCNQ potassium channels and epilepsy. Front. Biol. 2014, 9, 205-215. [CrossRef]

119. Cruzblanca, H.; Koh, D.S.; Hille, B. Bradykinin inhibits $\mathrm{M}$ current via phospholipase $\mathrm{C}$ and $\mathrm{Ca}^{2+}$ release from $\mathrm{IP}_{3}$-sensitive $\mathrm{Ca}^{2+}$ stores in rat sympathetic neurons. Proc. Natl. Acad. Sci. USA 1998, 95, 7151-7156. [CrossRef] [PubMed]

120. Selyanko, A.A.; Brown, D.A. Intracellular calcium directly inhibits potassium $M$ channels in excised membrane patches from rat sympathetic neurons. Neuron 1996, 16, 151-162. [CrossRef]

121. Alaimo, A.; Alberdi, A.; Gomis-Perez, C.; Fernandez-Orth, J.; Gomez-Posada, J.C.; Areso, P.; Villarroel, A. Cooperativity between calmodulin-binding sites in Kv7.2 channels. J. Cell Sci. 2013, 126, 244-253. [CrossRef]

122. Strulovich, R.; Tobelaim, W.S.; Attali, B.; Hirsch, J.A. Structural Insights into the M-Channel Proximal C-Terminus/Calmodulin Complex. Biochemistry 2016, 55, 5353-5365. [CrossRef] [PubMed]

123. Soldovieri, M.V.; Boutry-Kryza, N.; Milh, M.; Doummar, D.; Heron, B.; Bourel, E.; Ambrosino, P.; Miceli, F.; De, M.M.; Dorison, N.; et al. Novel KCNQ2 and KCNQ3 mutations in a large cohort of families with benign neonatal epilepsy: First evidence for an altered channel regulation by syntaxin-1A. Hum. Mutat. 2014, 35, 356-367. [CrossRef] 
124. Gomis-Perez, C.; Alaimo, A.; Fernandez-Orth, J.; Alberdi, A.; Aivar-Mateo, P.; Bernardo-Seisdedos, G.; Malo, C.; Areso, P.; Felipe, A.; Villarroel, A. Unconventional calmodulin anchoring site within the AB module of Kv7.2 channels. J. Cell Sci. 2015, 128, 3155-3163. [CrossRef] [PubMed]

125. Strotmann, R.; Schultz, G.; Plant, T.D. $\mathrm{Ca}^{2+}$-dependent potentiation of the nonselective cation channel TRPV4 is mediated by a C-terminal calmodulin binding site. J. Biol. Chem. 2003, 278, 26541-26549. [CrossRef] [PubMed]

126. Loukin, S.H.; Teng, J.; Kung, C. A channelopathy mechanism revealed by direct calmodulin activation of TrpV4. Proc. Natl. Acad. Sci. USA 2015, 112, 9400-9405. [CrossRef] [PubMed]

127. Yu, C.C.; Ko, J.S.; Ai, T.; Tsai, W.C.; Chen, Z.; Rubart, M.; Vatta, M.; Everett, T.H.; George, A.L., Jr.; Chen, P.S. Arrhythmogenic calmodulin mutations impede activation of small-conductance calcium-activated potassium current. Heart Rhythm 2016, 13, 1716-1723. [CrossRef] [PubMed]

2019 by the authors. Licensee MDPI, Basel, Switzerland. This article is an open access article distributed under the terms and conditions of the Creative Commons Attribution (CC BY) license (http:/ / creativecommons.org/licenses/by/4.0/). 